\title{
From Satirical Piece to Commercial Product: the Mid-Victorian Opera Burlesque and its Bourgeois Audience*
}

\author{
Abstract (150 words) \\ Current studies of burlesque position it as a subversive genre that \\ questioned cultural and social hierarchies and spoke to diverse audiences. \\ Central to this interpretation are burlesque's juxtapositions of high and low \\ culture, particularly popular and operatic music. This article problematizes \\ this view, proposing that mid-Victorian burlesques lost their satirical bite. \\ Demonstrating little concern for the tastes or interests of the poorer or the \\ most elite members of the audience, they specifically targeted the \\ bourgeoisie. The article places three mid-Victorian burlesques in the wider \\ context of the commercial development of the West End post the $185_{1}$ Great \\ Exhibition. It proposes that this broader context, and not the genre's \\ perceived social role, provides the key to understanding the impulses \\ driving the musical choices. It argues that juxtapositions of 'high' and 'low' \\ music were far from subversive, rather they were included for commercial \\ reasons, offering variety, but variety within strict bourgeois limits.
}

Over the last thirty years, musicologists have increasingly questioned the processes of canon formation and the assumed sanctity of the musical work. A significant outcome of this development within opera studies has included the increased attention paid by scholars to the idea of musical drama as event. This has had an important impact on which genres and composers are deemed worthy of study. Accordingly, opera studies have increasingly encompassed a wide variety of popular theatrical genres. Several important studies have established the performance practices and the role of music in particular popular genres. ${ }^{1}$ We are also beginning to see new, rigorous and critical overviews of the development of certain genres focussed on particular metropolitan centres. Melodrama, ballad opera, and operetta have been at the forefront of this type of research. ${ }^{2}$ These avenues of enquiry have encouraged scholars to unpick the rich relationships between popular theatrical genres, as well as those between popular and 'elite' genres, problematizing the distinction between the two. For example, the

\footnotetext{
* I would like to thank Roberta Montemorra Marvin for providing advice, and Sarah Hibberd and Christina Fuhrmann for reading drafts of this article. Any mistakes of fact or interpretation are my own. ${ }^{1}$ See Sarah Hibberd (ed.), Melodramatic Voices: Understanding Music Drama (Farnham, 2011) and Richard Traubner, Operetta: A Theatrical History (London, 1984).

${ }^{2}$ See Michael Pisani, Music for the Melodramatic Theatre in Nineteenth-Century London and New York (Iowa, 2014). Derek Scott's current ERC project, 'German Operetta in London and New York, 1907-1939: Cultural Transfer and Transformation' promises an equivalent rigorous study for operetta. Details of the project are available here: http://music.leeds.ac.uk/news/scotts-german-operetta-project-secures-eimerc-funding/ [accessed 23/02/2016]. Particular composers and works have also garnered interest, including the ballad operas of John Gay and Henry Fielding, and Johann Strauss's, Offenbach's and Lehár's operettas, forming a new type of 'canon.' See Calhoun Winton, John Gay and the London Theatre (Lexington, 1993), L.J. Morrissey, 'Henry Fielding and the Ballad Opera', Eighteenth-Century Studies 4 (1971), 386-402, Camille Crittenden, Johann Strauss and Vienna: Operetta and the Politics of Popular Culture (Cambridge, 200o), and Micaela Baranello, 'Die lustige Witwe and the Creation of the Silver Age of Viennese Operetta', Cambridge Opera Journal, 26 (2014), 175-202.
} 
relationship of ballad opera to both vaudeville and English opera has been the subject of several studies, as have exchanges between melodrama, opera, and film music. ${ }^{3}$

The Victorian opera burlesque appears as a poor relation amidst this wealth of scholarship. Although several stand-alone studies have been completed by musicologists, including Roberta Montemorra Mavin, Rachel Cowgill, and Laura Tunbridge, a large-scale critical overview of the development of the genre is yet to appear. ${ }^{4}$ Studies of opera burlesque have used the genre as a means of understanding broader issues, such as the reception of opera, including particular productions, and have considered the light it can shed on contemporary attitudes to cultural, political, gender, and societal norms. While these studies are fascinating and illuminating, we have not yet established how opera burlesque was related to the broader theatrical landscape of the West End, or to other musical and theatrical genres. Nor have we considered how these relationships may have changed at different points in the genre's development. We also have not examined the influence of managers' strategies and of contemporary musical tastes on the music employed. Until these issues are recognised, we run the risk of misunderstanding what opera burlesque reveals about broader cultural and social issues, and of treating it as a static genre divorced from the broader developments taking place around it.

Richard Schoch argues that the specific, formal features of burlesque are less important to our understanding of the genre than the function it performed as a 'sustained, self-conscious comic interpretation of a specific text.' 5 Nonetheless, we can point to some common characteristics: puns, music from a variety of genres, dance, topical references, and the domesticating and 'lowering' in status of settings and subjects. In addition, the 'source' texts most often came from Classical mythology, Shakespeare, and opera. Burlesque had a shifting relationship to other popular genres,

\footnotetext{
3 See Vanessa Rogers, 'John Gay, Ballad Opera and the Théâtres de la foire', Eighteenth-Century Music, 11 (2014), 173-213. Many writers have also drawn parallels between ballad opera and the development of English opera. See Frank Kidson, The Beggar's Opera: its Predecessors and Successors (New York, 1969) and Suzanne Aspden, 'Ballads and Britons: Imagined Community and the Continuity of 'English' Opera', Journal of the Royal Musical Association, 122 (1997), 24-51. Some studies on the interconnections between melodrama and opera and film music include: Sarah Hibberd, "Si L'Orchestre seul chantait": Melodramatic Voices in Chelard's Macbeth (1827)', in Melodramatic Voices: Understanding Music Drama (Farnham, 2011), 85-102, Mary Ann Smart, Mimomania: Music and Gesture in Nineteenth-Century Opera (Berkeley, 2004), and David Neumeyer, 'Melodrama as a Compositional Resource in Early Hollywood Sound Cinema', Current Musicology, 57 (1995), 61-94.

${ }^{4}$ See Roberta Montemorra Marvin, 'Verdian Opera Burlesqued: A Glimpse into Mid-Victorian Theatrical Culture', Cambridge Opera Journal 15 (2003), 33-66, Rachel Cowgill, 'Re-Gendering the Libertine: Or, the Taming of the Rake: Lucy Vestris as Don Giovanni on the Early Nineteenth-Century London Stage', Cambridge Opera Journal, 10, (1998), 45-66 and Laura Tunbridge, 'From Count to Chimney Sweep: Byron's “Manfred” in London Theatres', Music E Letters, 87 (2000), 212-236. Some older studies of burlesque offer descriptive overviews, rather than critical commentary, such as V. C. Clinton-Baddeley's, The Burlesque Tradition in the English Theatre after 1660 (London, 1952). Richard Schoch's Not Shakespeare: Bardolatry and Burlesque in the Nineteenth-Century (Cambridge, 2002) is an excellent study of Shakespeare burlesque. An equivalent is yet to appear for opera burlesques, which present different issues regarding national and cultural meanings, and the function and meaning of musical choices.

${ }^{5}$ Schoch, Not Shakespeare, 18
} 
combining ballad opera's use of satire ${ }^{6}$ with the spectacle of extravaganza, and the humour and direct addresses to the audience of pantomime. ${ }^{7}$ Eighteenth-century ballad opera ${ }^{8}$ is a particularly important precursor of burlesque because of the way music functions in both genres. Like burlesques, ballad operas were structured as plays with interpolated music, which was accessible, singable, and appropriated from a variety of sources: namely opera and ballads (urban and rural). ${ }^{9}$ In addition to these sources, burlesques also included minstrelsy and music hall. The pre-existing music was given new lyrics, creating comic intertextual references if audiences were aware of the original version.

Burlesques were popular throughout the nineteenth century, reaching their height in the 1860 and gradually displaced by opera bouffe and musical comedy from the 1870 . $^{10}$ They were, therefore, performed during a long period that saw considerable social, political, and theatrical change. An important aspect of this change involved how theatres were licensed. Traditionally, the Theatres Royal, Covent Garden and Drury Lane, had operated under Royal Patents granted by Charles II in 1662 . The patents had powerful implications because they granted monopoly over spoken, or 'legitimate', drama. The patents also ensured that the two theatres could perform any type of production all year round, as long as they received the approval of the Examiner of Plays at the Lord Chamberlain's Office, to whom all new plays were submitted for licensing, and who acted as censor. ${ }^{11}$ Other minor theatres received licences annually and were prohibited from producing spoken drama. ${ }^{12}$ Jane Moody has observed that in response the minor theatres produced 'illegitimate' theatrical pieces, such as burlesque, extravaganza, and pantomime, which relied on visual and musical expression in order to circumvent the prohibition on the use of dialogue. In practice, however, the difference between the productions offered by patent and minor theatres was not clear cut. The minor theatres found many ingenious ways around the licensing act, and the patent theatres, responding to competition, also staged a range of popular theatrical genres that showcased music and visual spectacle. ${ }^{13}$ The licensing situation was debated in 1832 by a Select Committee. The patent theatres became the subject of scrutiny because of their financial difficulties and their seeming lack of support for native talent. They complained of the

\footnotetext{
${ }^{6}$ Ballad operas satirised issues of the day and musical and theatrical tastes and practices. See Vanessa Rogers, 'John Gay, Ballad Opera and the Théâtres de la foire', Eighteenth-Century Music 11 (2014), 173-213 (189-191).

${ }^{7}$ For more detail on the development of burlesque from ballad opera and extravaganza, see Walter $\mathrm{H}$. Rubsamen, 'The Ballad Burlesques and Extravaganzas', Musical Quarterly 36 (1950), 551-561 and Michael Booth, English Plays of the Nineteenth Century: Vol. V: Pantomimes, Extravaganzas and Burlesques (Oxford, 1969-1976), 2-52.

${ }^{8}$ For a time ballad opera seemed to offer hope of an English operatic tradition, but its popularity was fleeting. The genre entered the theatre with the premiere of John Gay's The Beggar's Opera, and had declined around a decade later. See Eric Walter White, The Rise of English Opera (London, 1951), 69.

${ }_{9}$ Calhoun Winton, John Gay and the London Theatre (Kentucky, 1993), 111-116.

${ }^{10}$ Booth, English Plays of the Nineteenth Century, 38-40.

${ }^{11}$ During the period examined in this article, W. B. Donne fulfilled this role. He was Acting Examiner from 1849 to 1856 and Examiner of Plays from 1857 to 1874.

${ }^{12}$ For a fuller discussion of how the patents and licences worked, see Gabriella Dideriksen, 'Repertory and Rivalry: Opera at the Second Covent Garden Theatre, 1830 to 1856', Ph.D. diss. (King's College London, 1997), 18-65.

${ }^{13}$ Jane Moody, Illegitimate Theatre in London, 1770-1840 (Cambridge, 2000), 46.
} 
encroachment of the minor theatres onto the territory preserved by the patents and the ensuing competition this created. The minor theatres complained that, by putting on musical and spectacular entertainments at the expense of legitimate drama, the patent theatres were not fulfilling the obligations of their patents. ${ }^{14}$ Eventually, the minor theatres gained the right to stage legitimate drama with the Theatre Regulation Act of 1843. This act consolidated the power of the Lord Chamberlain to license theatres and read and censor texts of any pieces produced. ${ }^{15}$

Burlesque's position as an 'illegitimate' genre being produced in minor theatres that sought ways around licensing acts and censorship has naturally coloured scholars' readings of it. For Schoch, burlesque functioned as a site for articulating multiple and alternative political perspectives. He argues that burlesques often commented on contemporary political debates, particularly political emancipation, social class issues, republicanism, and revolution. Schoch acknowledges that burlesques took a variety of political attitudes, but the examples he examines question the status quo and imagine alternatives. ${ }^{16}$ Moody's ground-breaking research into illegitimate theatre characterised genres such as burlesque as challenging sites of 'political, moral and generic transgression', ${ }^{17}$ which enjoyed relative freedom from the censorship mechanisms. ${ }^{18}$ In consequence of this freedom, burlesques could critique contemporary political and social issues. ${ }^{19}$ Subsequent research on burlesque, whether undertaken by musicologists or theatre historians, has cemented its position as a subversive genre: a genre that unsettles cultural, social, and even gender norms and hierarchies. Fiona Macintosh proposes that burlesque acted as 'a relatively radical forum for serious debate. ${ }^{20}$ Laura Monrós-Gaspar argues that 'the fact of

\footnotetext{
${ }^{14}$ See Dideriksen, 'Repertory and Rivalry', 21 for details.

${ }^{15}$ Eric Walter White, A History of English Opera (London, 1983), 295.

${ }^{16}$ Schoch, Not Shakespeare, 151-187. Schoch also argues that burlesque functioned as a critique of contemporary Shakespeare performers and productions, reclaiming Shakespeare from those who would unintentionally harm him through 'bardolatry'. See eadem, Not Shakespeare, 4. See also, eadem, “'Chopkins, Late Shakespeare”: the Bard and his Burlesques, 1810-166', English Literary History 67 (2000), 973-991.

${ }^{17}$ Moody, Illegitimate Theatre, 2

${ }^{18}$ Moody, Illegitimate Theatre, 18. This is certainly true of the burlesques examined here. The manuscripts submitted to W. B. Donne and held at the British Library (Add MS 52991 P, Add MS 53047 G, Add MS 53073 D) show that licenses were granted within twenty-four hours, and there is no evidence that changes were requested. On other occasions the licensing process could be unwieldy, intrusive, and contradictory, demanding cuts, suppressing entire plays, and seeming to allow a play to be performed and then retracting the decision. See David Worrall, Theatric Revolution: Drama, Censorship and Romantic Period Subcultures 1773-1832 (Oxford, 2006), 103-132 for details. Worrall examines an earlier period than this article, but even later in the century the Examiner of Plays happily exercised his powers of censorship. See David Thomas, David Carlton and Anne Etienne, Theatre Censorship: From Walpole to Wilson (Oxford, 2007), 24-68.

${ }^{19}$ Moody argues that because illegitimate drama was so centred on visual and musical language, there was no provision for scrutinising their untraditional texts. (See Moody, Illegitimate Theatre, 18).

However, other researchers of censorship have found that the remit of the Examiner of Plays included genres such as pantomime, ballet, and song lyrics. (See Worrall, Theatric Revolution, 38.) Managers and playwrights would have found creative ways around censorship, perhaps through mime and improvisation, but it seems unlikely that such a subversive genre would enjoy the kind of freedom that Moody suggests.

${ }^{20}$ She argues that burlesques of Medea offered a forum to comment on contemporary debates about women's inequalities in marriage. See Fiona Macintosh, 'Medea Transposed: Burlesque and Gender on
} 
burlesquing - or subverting - a classical text embodies an act of transgression which...entails strong ideological concerns on the cultural division of the classes and a stagnant education system which was based on Classics as a status marker. ${ }^{21}$ Finally, Tunbridge emphasises the role of burlesque in providing 'social critique' and 'satire on contemporary social concerns' and 'theatrical hubris'. ${ }^{22}$ Overwhelmingly, studies of burlesque produce an impression of a genre that questioned the status quo, that imagined new social and political alternatives, that participated in controversial debates, and that traversed boundaries between classes and different cultural genres.

Following the 1843 Theatre Regulation Act, burlesque still proved popular and retained a regular position on the programme of most minor theatres because audiences continued to demand it, ${ }^{23}$ but the nature of burlesque changed. Burlesques in the second half of the nineteenth century have received less attention than those in the first, probably because the genre began to lose its satirical bite. ${ }^{24}$ Satire is often considered as challenging and critical, and this is largely how its role in opera burlesque has been understood until now. However, a significant school of literary theorists see satire as a conservative genre that upholds existing dominant norms. ${ }^{25}$ We will see that this conservative reading of satire is actually applicable to burlesques in the mid-Victorian period, which are less questioning of social norms and hierarchies than their predecessors. Tunbridge alludes to a change in the nature of the genre in her examination of two burlesques of Byron's Manfred: one from 1834 and one from 1863 . She notices that the social satire of the earlier burlesque is much more challenging than that of the later burlesque, which does not have the same 'contemporary resonance'. ${ }^{26}$ She links this difference to the change in theatre licensing, arguing that 'Fully licensed, burlesques lost their political potency, their ability to critique the establishment. ${ }^{27}$ Macintosh also alludes to a shift towards a 'more socially homogeneous, more solidly bourgeois audience' 28 in the last two decades of the century, but does not examine the implications of this change for burlesque. Finally, Schoch briefly mentions a change in burlesque towards the end of the century when the genre took on a distanced relationship to Shakespeare, and became more titillating and less satirical and critical. He associates this with audiences' lack of familiarity with Shakespeare due to their exposure to a restricted

the Mid-Victorian Stage', in Medea in Performance 1500-20oo ed. Edith Hall, Fiona Macintosh and Oliver Taplin (Oxford, 2000), 75-99 (82).

${ }^{21}$ Laura Monrós-Gaspar, Victorian Classical Burlesques: A Critical Anthology (London and New York, 2015), 15 .

${ }^{22}$ Tunbridge, 'From Count to Chimney Sweep', 219 and 222.

${ }^{23}$ George Rowell, The Victorian Theatre: a Survey (Oxford, 1967), 13.

24 The exception is Roberta Montemorra Marvin, who has examined mid-Victorian burlesque in a number of chapters and articles, including 'Verdian Opera Burlesqued'; eadem 'Handel's Acis and Galatea: A Victorian View', in Europe, Empire and Spectacle in Nineteenth-Century British Music ed. Rachel Cowgill and Julian Rushton (Aldershot, 2006), 249-264 and eadem 'Burlesques, Barriers, Borders and Boundaries', in Operatic Migrations: Transforming Works and Crossing Boundaries (Aldershot, 2006), 203-210.

${ }^{25}$ For an overview of the 'conservative' school of thought, see Amber Day, Satire and Dissent: Interventions in Contemporary Political Debate (Indiana, 2011), 11-12 and Linda Hutcheon, Irony's Edge: the Theory and Politics of Irony (London and New York, 1994), 28-9.

26 Tunbridge, 'From Count to Chimney Sweep', 231.

27 Tunbridge, 'From Count to Chimney Sweep', 235.

${ }^{28}$ Macintosh, 'Medea Transposed', 85. 
repertoire resulting from the fashion for long runs. ${ }^{29}$ This reluctance to examine changes in the genre after mid-century has led to a rather one-sided understanding, which overwhelmingly depicts the genre as laden with social and political potency, even in its later guise.

Few researchers have dealt seriously with the issue of who actually attended burlesques, even though this is central to understanding the messages burlesque was intended to convey..$^{30}$ Schoch proposes that through the use of slang language and references to drinking and fighting "burlesque constructed its audience as a collective of “fast" young men'. ${ }^{31} \mathrm{He}$ acknowledges that audiences may have been more diverse than this in reality, but argues that burlesque courted this particular bourgeois group. The reading seems to tell only part of a complicated story. Schoch's book spans burlesque across almost the whole of the nineteenth-century, but does not acknowledge changes in audience make-up across this period, across different burlesque theatres, or in response to developments in the West End more broadly. Tunbridge and Monrós-Gaspar agree that while burlesques were not exclusive, audiences were expected to be well-informed about the burlesque's subject matter: music, theatre, current affairs, and classical mythology. ${ }^{32}$ It follows that burlesque producers and writers expected audiences to enjoy a considerable degree of education.

More often, researchers assert that burlesque audiences were diverse. Macintosh tells us that, along with melodrama, farce and pantomime, burlesque shared 'a relatively broad-based audience' (at least until around 1870).33 Regarding classical burlesque, Monrós-Gaspar states that when touring burlesque productions were put on in small and provincial theatres to uneducated audiences much of the humour would have been produced by the performance, rather than by the parody of the original source subject. ${ }^{34}$ This suggests that audience make-up was variable depending on location, and different aspects of the production were enjoyed by different demographics. Similarly, Montemorra Marvin argues that mid-Victorian burlesques appealed to a broad sector of society, traversing class boundaries because the genre could communicate on different levels. ${ }^{35}$ Opera-goers would understand intertextual references and the 'shared territory' of 'external associations, localized allusions, and lampooning of social pretences and circumstances' would have appealed to a wide variety of people. ${ }^{36}$ Several researchers have understood the mixture of musical and theatrical genres that burlesque references and interpolates as an important aspect of

\footnotetext{
${ }^{29}$ Schoch, Not Shakespeare, 13.

$3^{\circ}$ Jim Davis has undertaken considerable work on theatre audiences, but has not examined burlesque specifically. Even so, his findings have been invaluable to this study. See Jim Davis and Victor Emeljanow, Reflecting the Audience: London Theatregoing, 1840-188o (Hatfield, 2001) and Jim Davis, 'Spectatorship', in Cambridge Companion to British Theatre 1730-1830 ed. Jane Moody and Daniel O' Quinn (Cambridge, 2007), 57-70. See also Michael Booth, 'East End and West End: Class and Audience in Victorian London', Theatre Research International, 2 (1977), 98-103.

${ }^{31}$ Schoch, Not Shakespeare, 131.

$3^{2}$ See Tunbridge, 'From Count to Chimney Sweep', 217 and Monrós-Gaspar, Victorian Classical

Burlesques, 10-11.

33 Macintosh, 'Medea Transposed', 85.

34 Monrós-Gaspar, Victorian Classical Burlesques, 12.

35 Marvin, 'Verdian Opera Burlesqued', 42.

${ }^{36}$ Marvin, 'Verdian Opera Burlesqued', 44.
} 
the genre's apparent appeal to diverse audiences. At the same time, these mixtures have often been seen as evidence of burlesque's subversive, challenging nature. Moody sees the lampooning of elite genres through frequent 'irreconcilable clashes and unresolved dissonances' and 'incongruous juxtapositions' as one of burlesque's main strategies for disrupting and questioning cultural, and implicitly, social hierarchies. ${ }^{37}$ Building on Moody's reading, Montemorra Marvin also highlights the juxtaposition of 'seemingly incongruous well-known repertories' and of 'traditional lower- and upperclass entertainments' 38 in mid-Victorian opera burlesque. She proposes that burlesque traversed cultural and social boundaries because it translated an 'artificial high art genre into an "earthy" low art form'. 39

Divisions between 'high art' and 'popular entertainment' were developing in the second half of the nineteenth century, but at the same time the status and meanings of popular music were complex. Building on recent Victorian reception studies, I argue that we need to consider carefully the relationship of the bourgeoisie to the popular genres used in burlesque, and beware of assuming that musical juxtapositions were necessarily received as incongruous or dissonant (and consequently challenging and subversive) $4^{40}$ The possible meanings created by placing a parlour ballad, music hall or minstrel song alongside an aria require closer scrutiny. Instead of reading juxtapositions as dissonant or as part of burlesque's broad appeal, I demonstrate that the musical choices in mid-Victorian opera burlesque were designed to appeal to a bourgeois audience. This is not to say that the make-up of audiences solely comprised the middle classes; the tiered pricing system ensured that burlesques were accessible to working-class people, and members of the gentry would also have attended. But I propose that producers of mid-Victorian burlesques demonstrated little concern for the tastes or interests of the poorer or indeed the most elite members of the audience. However, I also argue that producers targeted different demographics within the middle classes, depending on the strategies of the theatre managements and the time when the burlesques were performed. In examining the music in mid-Victorian burlesque, I shed new light on the ways in which West End theatre managers perceived middle-class cultural tastes and values and the bourgeois relationship to opera. At the same time, a safer, respectable and commercial image of burlesque begins to emerge.

Historians regularly examine the Victorian middle classes: their leisure pursuits, home-life, gender roles and a whole range of other topics, ${ }^{41}$ but there still exists

\footnotetext{
37 Moody, Illegitimate Theatre, 82.

${ }^{38}$ Montemorra Marvin, 'Burlesques, Barriers, Borders, and Boundaries', 206-209.

39 Montemorra Marvin, 'Verdian Opera Burlesqued', 44.

$4^{\circ}$ Derek Scott argues that 'high- and low-status music cannot be mapped directly onto high- and lowclass consumers'. See Derek Scott, Sounds of the Metropolis: the Nineteenth-century Popular Music Revolution in London, New York, Paris, and Vienna (New York, 2008), 9. Paul Rodmell has also highlighted the diversity of opera audiences in the provinces during the Edwardian period, arguing that opera was more affordable and accessible, and audiences 'far less socially segregated' than in the West End. All of this problematizes traditional categories of high art and popular entertainment. See Paul Rodmell, Opera in the British Isles, 1875-1918 (Farnham, Surrey, 2013), 131-183.

${ }^{41}$ Some influential texts that have focussed on these issues include: John Tosh, A Man's Place:

Masculinity and the Middle-Class Home in Victorian England (New Haven, Conn.; London, 2007);
} 
considerable disagreement regarding the definition of exactly who they comprised. Like William Weber, I see the middle classes as a 'frequently self-conscious social group but neither monolithic nor unified.' 42 There would, of course, have been vast disparities in income, occupation, social circle, and cultural tastes and knowledge. Historians have found a number of ways of dealing with this diverse and complicated group of people. In her study of Victorian middle-class art collecting, Diane Sachko Macleod focuses on individuals before drawing conclusions about broader groups. This enables her to construct the Victorian middle-class art collector in more depth and detail than previously possible, and it allows her to refute some hackneyed stereotypes. ${ }^{43}$ Unfortunately, there are no records of purchasers of burlesque tickets so it is not possible to reproduce the detail of Macleod's focus on individuals in this study. However, I have tried to be as specific as possible about the group of people being discussed, referring to their occupations or where they fell on the income spectrum. More often, I have used an approach put forward by Elizabeth Langford in her study of Victorian etiquette manuals. Langford argues that we should not understand these manuals as a reflection of a "real" historical subject' but as documents deliberately intended to 'construct' and 'consolidate' a genteel middle class, by distinguishing this group from the working classes and other factions of the middle classes. ${ }^{44}$ Similarly, this article draws on advertising, newspaper reviews, and the texts and music of the burlesques themselves, to identify how burlesque audiences were constructed, rather than who they comprised in reality.

Dror Wahrman argues that the middle class never was a tangible entity, but an imagined body that existed somewhere within the 'space of possibilities between social reality and its representations.' 45 Its position within this space of possibilities would change according to the needs of the time (political in Wahrman's study). Wahrman examines the different ways in which the middle class was imagined in political language at important moments between 1780 and 1840, suggesting that the vagueness of the definition of the middle class was often useful. Similarly, I argue that different West End theatre managers imagined this heterogeneous, ambiguous and fluid body of people in different ways. I seek to nuance our understanding of burlesque, tracing the steady 'bourgeoisification' and commercialisation of the genre ${ }^{46}$ by examining three opera burlesques across the 1860 s, a key decade in the transition of the West End:47 L.S. Buckingham's Lucrezia Borgia! at Home and All Abroad, performed at the St James's Theatre, 16 April 1860, H.J. Byron's Little Don Giovanni, or Leporello and the Stone Statue, performed at the Prince of Wales's Theatre, 21 December 1865, and W.S.

Elizabeth Langland, Nobody's angels: Middle-class Women and Domestic Ideology in Victorian Culture (Ithaca, 1995); Thad Logan, The Victorian Parlour: A Cultural Study (Cambridge, 1991).

$4^{2}$ William Weber, 'The Muddle of the Middle Classes', $19^{\text {th }}$-Century Music, 3 (1979), 175-185 (180).

43 Dianne Sachko Macleod, Art and the Victorian Middle Class (Cambridge, 1996), 1-14.

44 Elizabeth Langford, Nobody's Angels, 27-9.

45 Dror Wahrman, Imagining the Middle Class: The Political Representation of Class in Britain, c. 178o1840 (Cambridge, 1995), 8.

${ }^{46}$ The development of burlesque in the second half of the nineteenth century into a "bourgeoisified", commercial genre mirrors the concurrent 'popular music revolution' which Derek Scott has argued was driven by a capitalist economy and the consolidation of power of the bourgeoisie. See Scott, Sounds of the Metropolis, 8.

47 Davis and Emeljanow identify the period $1851-1880$ as a time of rapid development in the West End with a boom in theatre building after 1866. See Reflecting the Audience, 179-185. 
Gilbert's Robert the Devil, or the Nun, the Dun, and the Son of a Gun, performed at the Gaiety Theatre, 21 December 1868. These burlesques were written by some of the most well-known, successful, and prolific burlesque writers of their time and so are representative of trends in the genre. They are also illuminating because, as we will see, they indicate that the musical choices for different burlesques could operate according to different models in order to appeal to different types of audiences within the fluid and heterogeneous Victorian middle class. Accordingly, I examine the particular circumstances of each theatre, demonstrating important differences at three theatres with seemingly similar clienteles and located in close proximity within London's West End. In doing so, I demonstrate the importance of considering nuances in audiences, theatres, and musical choices in understanding the genre of burlesque and the way it was received.

Examining burlesque presents significant philological issues. Burlesque writers and producers viewed the genre as something disposable, to be written and produced quickly and then replaced by the next burlesque. Accordingly, those involved in burlesque productions appear to have been little concerned with preserving their work. Fortunately, the texts of many burlesques did make it into print, usually to enable provincial theatre companies to stage the same burlesques produced in London. ${ }^{8}$ The British Library also holds a large collection of burlesque manuscripts submitted to the Examiner of Plays. Many texts, therefore, are preserved either in manuscript or printed form, but unfortunately this is not the case regarding the music. No scores or parts have yet emerged for the productions discussed here, and this seems to be the norm as regards burlesque. ${ }^{49}$ Writers and arrangers evidently felt little need to preserve musical scores and parts, possibly because the music was usually preexisting and so the original sources could be used if the burlesque were to be produced elsewhere. The titles of the music in burlesques are identified in the printed libretti and manuscripts. These provide a good indication of the tune to which the lyrics were to be sung, but often titles are incomplete or misspelled. In several cases the new lyrics provide the key to identifying the source. The Victoria and Albert Museum Theatre and Performance Archive holds some burlesque libretti alongside a wealth of other related material, including playbills, images of performers, productions and theatres, and newspaper clippings of reviews, which help to put flesh on our understanding of this fascinating genre.

\section{Cleaning up Burlesque}

In the first half of the nineteenth century, the theatre had a tarnished reputation as a place of moral transgression and the display of public sexuality..$^{\circ}$ Dimly lit foyers and boxes offered prime locations for assignations with prostitutes and private drinking. However, by 1880 the theatres of the West End were considered impeccably respectable. This transformation has often been perceived as a middle-class reclamation of the theatre, but Jim Davis and Victor Emeljanow have argued that

\footnotetext{
${ }^{48}$ Schoch, Not Shakespeare, 110.

49 The exception can be found in Tunbridge's article. She includes a transcription of one of the numbers from Gilbert Abbott à Beckett's Man-Fred. The rest of the discussion of music is based on the lyrics and titles provided in libretti. See Tunbridge, 'From Count to Chimney Sweep', 217-30.

${ }^{50}$ Hugh Maguire, 'The Victorian Theatre as a Home from Home', Journal of Design History 13 (2000), 107-121 (107).
} 
contemporary partisan writers, such as Charles Dickens and Clement Scott, interested in promoting the theatre's redemptive powers, embellished such narratives. Instead, they argue that the transformation was more strongly influenced by capitalist rather than moral factors: the West End's newfound respectability was intrinsically bound to its commercialisation. ${ }^{11}$ Of course, the West End and its theatres had long been associated with commercial entertainment, but historians have observed a change mid-century, which saw the area become 'a site of mass consumption'. ${ }^{22}$ Earlier in the century the City of London was the centre of commercial life, but by mid-century, the West End contained the most sumptuous shops and the best entertainment.

Developments in retailing, publishing, tourism, advertising, transportation, and new institutions all contributed to the West End's development into a 'shopping district, tourist site, [and] entertainment centre' that was particularly attractive to bourgeois women. 53

These broader commercial changes are mirrored in the development of the West End's theatres. Financial depression from the 1830 and 40 and the loss of a local audience, as the West End's regular, affluent patrons moved out to the suburbs, contributed to what Davis and Emeljanow have described as a period of uncertainty, resulting in a cessation in theatre-building between 1843 and 1866. Consequently, theatre managers were forced to consider new ways of targeting new audiences. An important part of the strategy was to 'offset' the 'decrease in regular playgoers by turning the West End itself into an elaborate theme park' that appealed to tourists. ${ }^{54}$ In order to do this, managers would try to recreate the 'sense of occasion', 'respectability', 'sense of wonder', and 'competitiveness' of the Great Exhibition. 55 Tourism offered an important incentive to improve the respectability of the West End, as it was vital that visitors felt safe. Increased wages, better transport links, and an outflow of Londoners to the suburbs, meant that the typical West End tourist was middle-class, and theatre managers began to target bourgeois consumers who had travelled to London from the provinces, or suburbs, as did managers of West End department stores. ${ }^{6}$

The development of mid-Victorian burlesque has not been examined against this context, but it too should be understood as part of this broader 'bourgeoisification' and commercialisation of the West End, driven in part by tourism. In the new theatrical climate of increasing respectability it might have been expected that a subversive, transgressive, irreverent genre like burlesque might not survive, but as Montemorra Marvin has shown, burlesque continued to thrive, and 'by the 1880 os, almost every truly popular opera had become the subject of a burlesque'. ${ }^{77}$ Certainly, there was an underlying anxiety that burlesque's past as a site of subversion and its future (which some feared was in a vulgarised version of the genre) meant that it was a potentially dangerous genre which could easily become disreputable. For example, a

\footnotetext{
${ }^{11}$ Davis and Emeljanow, Reflecting the Audience, 168-9 and 173.

${ }^{2}$ Erika Rappaport, Shopping for Pleasure: Women in the Making of London's West End (Princeton, 2000), 4. Rappaport has highlighted this change in her study of how the West End became constructed as a place of pleasure for bourgeois women.

53 Rappaport, Shopping for Pleasure, 4-8.

54 Davis and Emeljanow, Reflecting the Audience, 172.

55 Davis and Emeljanow, Reflecting the Audience, 170-2.

${ }^{56}$ See Davis and Emeljanow, Reflecting the audience, 179-182 and Rappaport, Shopping for Pleasure, 9.

57 Montemorra Marvin, 'Verdian Opera Burlesqued', 38.
} 
writer for The Examiner criticised the lowest common denominator humour found in some burlesques:

Mr F. Talfourd, Mr William Brough, and Mr Byron, the chiefs of the modern school of burlesque, are all capable of dispensing with the affectations of wit that are now practised for delusion of the ignorant[...]Is it not, then, worse than superfluous that they should spoil their sport with a mere strain after false wit, and aim also by the use of slang words that take the place of humour with the idle and stupid, to amuse the worse at the cost of annoyance to the better half of any but a taproom audience?58

Implicit in the criticism is the idea that the slipping standards of burlesque made it vulnerable to appropriation by the vulgar society found in taverns. Peter Bailey has found that the middle classes feared that their social identity could be compromised during leisure hours, because leisure activities were not always clearly demarcated across social lines. Consequently, there was a risk that a middle-class person may inadvertently end up enjoying a similar entertainment to someone from a lower social class. 59 If burlesque was to be demarcated as middle-class entertainment, its difference from working-class culture's vulgarity and lack of respectability must be highlighted. Differentiation from the working classes was important across the middle classes for various reasons. The lower-middle classes were concerned with 'separating themselves from their inferiors' ${ }^{60}$ because they had emerged from the working classes and did not want to return. Other sectors of the middle class were 'susceptible to the desire to improve manners and morals' ${ }^{6}$ and were, therefore, suspicious of the perceived vulgarity, violence, and acceptance of drinking and licentiousness of working-class culture. For others their behaviour and tastes were converging with the aristocracy, ${ }^{62}$ and they were also suspicious of the working classes as potentially irresponsible agitators' ${ }^{3}$ who might upset social stability as had happened on the continent. For all of these reasons, differentiation from working-class culture and 'bourgeoisification' of the genre proved important strategies to ensure the continued commercial success of burlesque.

Reviews of burlesques throughout the 1860 showed sensitivity towards potential vulgarity and dissolution. A review of the performance of L'Africaine; or, The Queen of the Cannibal Islands at the Strand on 18 November 1865 contains an interesting example of how the audience apparently dealt with a potentially scandalous event:

\footnotetext{
58 'The Theatrical and Musical Examiner', The Examiner, 14 April 186o. Punch magazine contained similar criticisms of the slipping standards of burlesque in 1865: 'A pretty story, neatly and dramatically told, opportunities for arch and graceful or humorous acting, smart satire, and ingenious allusions to topics of the time, pointed writing, and well-timed parodies, were expected in a burlesque [...] burlesques of this kind imply wit in Authors and art in Actors; both things difficult to find, and which, when found, come expensive.' 'Mr. Punch's Handy-book of the Stage', Punch, 25 February $1865,77$. 59 Peter Bailey, Popular Culture and Performance in the Victorian City (Cambridge, 1998), 17. ${ }^{60} \mathrm{~S}$. G. Checkland, The Rise of Industrial Society in England 1815-1885 (London, 1964), 301.

${ }^{61}$ J. M. Golby, The Civilisation of the Crowd: Popular Culture in England, 1750-190o (London, 1984), 84. ${ }^{62}$ This is a central argument of Martin Wiener's English Culture and the Decline of the Industrial Spirit, 1850-1980 (Harmondsworth, 1985). Wiener argues that the middle classes and aristocracy accommodated one another, sharing similar tastes, education and values, leading to a 'culture of containment' and the decline of industrialism in England.

${ }^{6}$ Checkland, The Rise of Industrial Society in England, 304.
} 
In the stalls, which were occupied for the most part by ladies and gentlemen, manifestly of good social position, and all dressed in evening costume, there was seated, in company with a friend, a tall and remarkably pretty woman, the extraordinary lowness of whose dress was a general subject of observation, and obviously gave great scandal to the audience, among the female portion of whom a painful sensation was clearly perceptible. At last public indignation found expression in a brief emphatic form. No sooner had the curtain fallen on the first play than there was heard from the gallery a voice uttering in slow and well-measured accents an injunction which could be intended but for one person in the vast assembly. Pale with emotion, yet still retaining her gentle, placid look - for there was no taint of immodesty in her demeanour - she quietly drew her opera cloak over her shoulders, and then tied it tightly round her neck. In a few minutes afterwards she rose from her seat, and, leaving behind her friend, a modestly-dressed woman, walked out of the house, amid hisses from the gallery and stern silence, not less eloquent, in the stalls and boxes. ${ }^{64}$

This account may have been imagined or at least embellished. Many critics, journalists, and social commentators attended West End theatres and published reviews and comment pieces that were motivated by a desire for the theatre to be a place of moral and social improvement and education. ${ }^{65}$ In general it is important to treat reviews with scepticism because most London newspapers of the time were indebted to political groups, and it was also standard practice for theatre managers to offer free tickets in exchange for positive reviews. ${ }^{66}$ At the same time, reviews are often the only sources for gaining insight into the performance practices and reception of particular productions. This particular piece suggests that the question of respectability was of high importance to the reviewer, and probably also to burlesque producers and audiences during the 186os. Past associations between the theatre and prostitution may also explain the description of the reassuringly strong reaction to the offence caused by the immodestly dressed woman. Even if the account was fictional, the fact it was written at all suggests a shift in opinion about burlesque, especially when considered against other positive press notices.

It was precisely its bourgeois popularity that led commentators to defend burlesque and reclaim it for the middle classes. For example, an article in The Times on W. S. Gilbert's burlesque of Robert le diable was clear that 'Like the other extravaganzas from Mr Gilbert's pen, Robert the Devil shows an endeavour to avoid the ordinary vulgarities of grotesque drama, and bring its most elegant contingencies into the

\footnotetext{
${ }^{64}$ 'Strand Theatre', The Morning Post, 20 November 1865, 6. The Morning Post was aligned with Lord Palmerston's liberal government and was mostly circulated amongst the nobility and gentry. See Lucy Brown, Victorian News and Newspapers (Oxford, 1985), 18 and 61.

${ }^{65}$ For details of how the narrative of the moral transformation of West End theatres was constructed see Davis and Emeljanow, Reflecting the Audience, 97-164.

${ }^{66}$ See Brown, Victorian News and Newspapers, 61 and Theodore Fenner, Opera in London: Views of the Press 1785-1830 (Illinois, 1994), 7-10.
} 
foreground' ${ }^{67}$ In fact, an article dedicated to Gilbert's achievements in The Illustrated Sporting and Dramatic News credited him with reforming burlesque by purging it of 'music-hall melodies, stale puns, low comedians in women's clothes, and the incessant and unvarying breakdowns of old-fashioned burlesque'. ${ }^{68}$ Clearly the elements associated with working-class culture were at issue here: the music, the vulgar humour, and the unsightly physicality of the 'breakdown' dances associated with blackface minstrelsy. Similarly, a review of the 1860 St James's Theatre production of Lucrezia Borgia! was approving, finding that 'the points of the opera are adroitly taken up, and applied without vulgarity'. ${ }^{69}$ A genre once associated with 'vulgarity, lowness, political radicalism and cultural subversion' 70 was now being praised for its taste, elegance and respectability.

Not only were references to working-class music and dance less tolerated during the mid-Victorian period, the subject matter and tone of opera burlesques also changed. They contained innocuous language and little sexual innuendo (unlike music hall performances). There was also minimal social satire. One brief reference can be found in Lucrezia Borgia! in which criticism of high income taxes provided material for one of the songs sung to the tune of 'The Glorious Vintage of Champagne' (see Table 1 for full details of the music in Lucrezia Borgia!):
When income tax we're forced to pay,
Of tenpence in the pound,
And for the hope 'twill end some day
There's not the slightest ground
One compensation doth remain -
'Tis all you'll get, I fear -
The glorious vintage of champagne
As cheap as ginger beer..$^{7}$

The high rate of income tax was an important issue for the middle classes, as they felt they were taxed unfairly. ${ }^{72}$ Rising incomes meant that many of the lower-middle classes were only just over the income-tax-paying threshold and ended up being overtaxed. ${ }^{73}$ The working classes did not earn enough to pay income tax and so were unaffected. ${ }^{74}$ Such references, therefore, were directed expressly at the middle classes as a criticism of policy that directly affected them. However, the political satire in this

\footnotetext{
67 The Times, Dec 24, 1868, Newspaper cutting 'Theatre Box: Gaiety 1868', VEA Museum Theatre and Performance Archive (hereafter V\&A). Like The Morning Post, The Times was also bought by the nobility and gentry, carrying advertisements for servants. It also had an extensive business section and appealed to City workers. Brown, Victorian News and Newspapers, 18 and 245-6.

68 The Illustrated Sporting and Dramatic News, 1 January, 1876 'Theatre Box: St James's Theatre 1866', $V \mathcal{E} A$.

69 Unlabelled newspaper cutting dated April 14 186o, ‘Theatre Box: St James's Theatre 186o', VEA [Date added post hoc].

${ }^{70}$ Moody, Illegitimate Theatre, 4.

${ }^{71}$ The song lyrics are not provided in the manuscript submitted to the Examiner of Plays (Add MS 52991

P), but they do appear in the published playbook. See Leicester Silk Buckingham, Lucrezia Borgia! At

Home and all Abroad in Lacy's Acting Edition of Plays. Vol. 45 (London, 1860), 27.

${ }^{72}$ Roger King and John Rayner, The Middle Class (London, 1981), 49.

73 Ian St. John, Gladstone and the Logic of Victorian Politics (London and New York, 2010), 200.

74 Between 1854 and 1875 the exemption limit for income tax was $£ 100$. People earning from $£ 100-150$ paid tax at a lower rate. See Geoffery Best, Mid-Victorian Britain 1851-75 (London, 1979), 101.
} 
instance is rather light-hearted. It displays precisely the qualities that have led literary theorists to argue that satire is often conservative; it criticises an individual concept, rather than the broader system, suggesting that particular aspects of it are fallible, but that the system itself is sound. It also functions as a 'safety valve', allowing writers and audiences a release for their frustrations without inciting concrete action. ${ }^{75} \mathrm{Mid}-$ Victorian burlesques certainly did not criticise the aristocracy or the political system in any serious way. Gentle mockery was in evidence rather than the 'willingness to "smash the aristocracy" 76 demonstrated by Gilbert Abbot à Beckett in earlier burlesques. It could perhaps be argued that the song's reference to taking comfort in alcohol could be a considered in a challengingly satirical light, especially considering the number of temperance movements at the time. However, the fact that the alcohol is champagne rather than beer would have mitigated potential for controversy. The song goes on to sneer at the poor quality of this cheap champagne, suggesting that its purpose was to appeal to refined tastes:

For many folks I've heard complain,

And much I fear 'tis true,

That low-priced vintage of champagne

Is cheap and nasty, too.

Chorus: Then let us carefully refrain

From that cheap vintage of champagne. ${ }^{77}$

The lowering of characters' social status was another common means of introducing political satire in burlesque in the first half of the nineteenth century, ${ }^{78}$ but this, too, is missing from the three burlesques under discussion here. Either the circumstances of the characters are unchanged in the burlesque, or the characters are given bourgeois social standing: making money in property or interested in stocks and shares and financial speculations. Topical references were still included, but with the purpose of defining the middle-class audience rather than disrupting the status quo. For example, the Gaiety's Robert the Devil production contained references to appropriate and inappropriate holiday destinations: citing Boulogne sur Mer as appropriate to the 'popular gentility', whilst Margate is to be sneered at, and assuming that those who holiday in Boulogne will not 'feel altogether up to Rome.'79

Holiday destinations emphasised class difference, with different 'social tones' at each resort. ${ }^{80}$ Margate was familiar to Londoners because it was close enough to go for the day. This seaside town mostly attracted working-class and lower-middle-class day trippers, ${ }^{81}$ and it is likely that many in the audience would indeed have sneered at it.

\footnotetext{
75 See Day, Satire and Dissent, 11-12.

${ }^{6}$ Tunbridge, 'From Count to Chimney Sweep', 219.

77 Leicester Silk Buckingham, Lucrezia Borgia! At Home and all Abroad, 28.

$7^{8}$ Tunbridge, 'From Count to Chimney Sweep', 220. Tunbridge has pointed to its use in Man-Fred, in which Count Manfred is a chimney sweep.

79 W. S. Gilbert, Robert the Devil; or, The Nun, the Dun, and the Son of a Gun (London, 1868), 35.

${ }^{80}$ Golby, The Civilisation of the Crowd, 157.

${ }^{81}$ Stephen Page, Tourism Management: An Introduction $4^{\text {th }}$ ed. (London and New York, 2011), 55. Those of the middle classes who were lower down the income scale would have holidayed in the UK, and many people from the lower-middle classes and working classes enjoyed day trips. See Best, Mid-

Victorian Britain 1851-75, 222-228.
} 
On the other hand, foreign holidaymaking was an important indicator of social standing as such excursions allowed the middle classes to imitate aristocratic behaviours and tastes. ${ }^{82}$ The first package foreign holidays pioneered by Thomas Cook were aimed at the upper-middle classes; the working and lower-middle classes were priced out. ${ }^{83}$ The preference for Boulogne reflected Rome's closer association with the aristocracy, as a key destination on the grand tour. It perhaps also mirrored the tastes of the Gaiety audience, who demanded entertainment rather than education, and may well have preferred a seaside holiday to a cultural experience. ${ }^{84}$ Evidently, the Gaiety management constructed its audience in quite a specific way, encouraging them to identify with and enjoy the sentiments of snobbery and lack of stomach for an aristocratic cultural experience.

\section{Misunderstanding the Audience: Lucrezia Borgia! at the St James’s Theatre}

The newfound respectability of burlesque, its differentiation from working-class culture, and its bourgeois appeal can be found most clearly in its music. This is certainly true of Lucrezia Borgia! performed at the St James's Theatre in April 1860. We have already seen that in 1860 the theatres were beginning to benefit from the newfound respectability of the West End, but they were only just beginning to develop the mass consumerism and promotional strategies that would encourage middle-class and fashionable publics to flood to the West End. ${ }^{85}$ The Lucrezia Borgia! production also occurred at a difficult time in the St James's history.

The St James's Theatre opened in December 1835 by the famous tenor, John Braham, as a potential home for English opera, and appealed to fashionable, upper-middleclass audiences. A major boon was the patronage of Queen Victoria, who regularly attended through the 1840 and 50 . Braham did not last long as manager and was succeeded by John Mitchell, who introduced French plays and opera, given in the original language. This was successful and through the 1840 os the St James's became known as 'the French theatre'. ${ }^{86}$ However, the taste for French theatre waned. Mitchell reacted by bringing in German companies, but these performances failed to appeal and he eventually gave up on the St James's. ${ }^{87}$ The theatre struggled to position itself from the mid-1850s and saw several managers come and go. At the beginning of 1859 the upper-tier ticket prices at the St James's Theatre (see Appendix Table 1) were far higher than the Gaiety or Prince of Wales's prices (see Appendix Tables 2 and 3). The worst seats in the theatre would have been within the reach of the upper-working classes, but generally ticket prices were not set in order to encourage the workingclasses to attend. ${ }^{88}$

\footnotetext{
${ }^{82}$ Stephen Williams, Alan A. Lew, Tourism Geography: Critical Understandings of Place, Space and Experience $3^{\text {rd }}$ ed. (New York and Oxford, 2015), 38.

${ }^{8} 3$ Francis Michael Longstreth, The Rise of Respectable Society: A Social History of Victorian Britain 18301900 (London, 1988), 262.

${ }^{84}$ See the final section of the article for more detail on Gaiety audiences.

85 These strategies would become even more pronounced at the turn of the century and the advent of musical comedy. See Rappaport, Shopping for Pleasure, 178-214.

${ }^{86}$ Barry Duncan, The St. James's Theatre: Its Strange and Complete History 1835-1957 (London, 1964), 60.

87 W. Macqueen Pope, St James's: Theatre of Distinction, (London, 1958), 42.

88 To put these prices into perspective, in the 1860 s, working-class men could earn anything between $35 \mathrm{~s}$ (as a skilled craftsman) and 12s (as a general labourer) per week. Middle-class males could earn between
} 
However, in October 1859 a new manager, F. B. Chatterton, took over and slashed prices (see Appendix Table 4). October's playbills show that the best seats in the house were now priced at $£ 22$ s rather than $£ 33$ s and the gallery at $6 \mathrm{~d}$ instead of $1 \mathrm{~s}$. The gallery and pit prices were emphasised, advertised in bold at the top of the playbill. The reduced prices were commented on in the press, which noted that Chatterton did not 'mean to depend on the aristocratic neighbourhood in which the house is situated. The choice of pieces also comes as proof.' 89 Theatre protectionists worried that the strategy of slashing prices boded ill for the theatre, fearing that a less affluent audience would spell decline in both behaviour and repertoire..$^{90}$ Indeed the St James's Theatre received criticism in the press for showing pieces of 'folly' and 'ribald vulgarity'. ${ }^{1}$ Chatterton did not manage to carve out a niche for the theatre. It was criticised for showing stale burlesques that were lacking in humour' ${ }^{92}$ and a 'miscellany of performances of little note.'93 Prices gradually climbed back up and by the mid-186os were similar to the other minor theatres under consideration here. The theatre now showed a better class of comedy than that programmed in the late 1850 . It regularly advertised 'legitimate comedy' alongside Shakespeare and other types of 'legitimate drama'. However, at the time of the Lucrezia Borgia! performance the prices remained on Chatterton's reduced scale.

Nonetheless, the St James's Theatre could still rely on its past reputation as a fashionable favourite of Queen Victoria and it offered a sumptuous setting with 'a gorgeous chandelier', 'golden ornaments' on the boxes and balconies, and 'deep crimson draperies'. ${ }^{44}$ Therefore, the theatre's audience in 1860 is difficult to identify. Chatterton's prices were clearly aimed at a working- and lower-middle-class audience, yet some of the older, more fashionable audience would probably still have attended. The audience at the St James's at this time was likely the most diverse among the audiences of the three theatres considered here and this is reflected in the reception of Lucrezia Borgia!

The structure of the burlesque, as a play with interpolated songs, is indebted to ballad opera. However, the music in Lucrezia Borgia! includes a greater proportion of operatic numbers than traditionally found in ballad opera. This also differs from the other two burlesques considered here. Five of the numbers drew on music from the original opera in equivalent places within the narrative, compared to three from Don Giovanni and one from Robert le diable (see tables 1, 2 and 3). Most of the other numbers were also taken from continental opera - Norma, Martha, and La gazza ladra. The audience were assumed to be familiar with the plot, characters, and music

\footnotetext{
$£ 150$ a year (a junior clerk’s salary) to £10oo a year (a London doctor or lawyer's salary). See Geoffrey Best, Mid-Victorian Britain 1851-75, 115-17 and 109-10.

89 Unlabelled Newscutting dated 8 October 1859, 'Theatre Box: St James's Theatre 1859', VEA [Date added post hoc].

90 'The Dramatic and Musical World of London', J. V. P. Baily's Monthly Magazine of Sports and

Pastimes, 1 May, 186o, 177.

$9^{1}$ Unlabelled Newscutting dated 8 October 1859, 'Theatre Box: St James's Theatre 1859', VEA [Date added post hoc].

92 'The Dramatic and Musical World of London', J. V. P. Baily's Monthly Magazine of Sports and Pastimes, 1 March, 1860, 52.

93 'The Dramatic and Musical World of London', J. V. P. Baily's Monthly Magazine of Sports and

Pastimes, 1 September, 1860, 431.

94 Duncan, The St James's Theatre, 16.
} 
of the original opera. In presenting the opera in an English adaptation, the burlesque catered to the widely-held, middle-class suspicion of Italian opera as a foreign art form. The adaptation would also have resonated with the common practice of presenting continental opera in English and of providing Italian arias in sheet music versions with new English lyrics, such as the arrangements made by Charles Jeffery of music from Norma and Il trovatore (incidentally, two operas drawn upon by the burlesques examined here).

Table 1: Music in Lucrezia Borgia!

\begin{tabular}{|c|c|}
\hline Title & Origin \\
\hline Song.-Orsini. Air, 'Billy Taylor' & Popular ballad based on a traditional Scottish air. \\
\hline $\begin{array}{l}\text { Dance music without, 'La Danza } \\
\text { Invitaci' }\end{array}$ & Lucrezia Borgia (Donizetti) \\
\hline $\begin{array}{l}\text { Song. -Lucrezia.- Air, 'Com' e [sic] } \\
\text { bello' }\end{array}$ & Lucrezia Borgia \\
\hline $\begin{array}{l}\text { Air, 'Come where my love lies } \\
\text { dreaming' }\end{array}$ & Parlour song by Stephen Foster. \\
\hline $\begin{array}{l}\text { Song-Johnny.- Air, 'Di Pescatore } \\
\text { Ignoble [sic]' }\end{array}$ & Lucrezia Borgia \\
\hline Concerted Piece,-Air, from Martha & (Flotow) The particular number is not specified. \\
\hline $\begin{array}{l}\text { Song-Lucrezia.-Air 'Limerick } \\
\text { Races' }\end{array}$ & $\begin{array}{l}\text { Comic Irish Music Hall Song sung by Irish entertainer } \\
\text { and music hall owner Sam Collins. Composed by } \\
\text { William Grantham. }{ }^{95}\end{array}$ \\
\hline $\begin{array}{l}\text { Song-Johnny.-Air, 'Whar do you } \\
\text { come from?' }\end{array}$ & Minstrel song by Joel Sweeney. \\
\hline $\begin{array}{l}\text { Concerted Piece.-Air, 'Guerra, } \\
\text { guerra!' }\end{array}$ & Norma (Bellini) \\
\hline $\begin{array}{l}\text { Trio-Lucrezia, Alfonso and Johnny. } \\
\text { Air, 'Deh con te' }\end{array}$ & Norma \\
\hline [Changes to] Air, 'Skid-a-ma-link' & Unidentified \\
\hline Song-Lucrezia. Air, 'Topsy's Song' & $\begin{array}{l}\text { Refers to 'Oh! I'se so wicked'. Written by George } \\
\text { Howard for performance in his company's } \\
\text { dramatization of Uncle Tom's Cabin. }\end{array}$ \\
\hline $\begin{array}{l}\text { Trio.-Lucrezia, Alfonso, and } \\
\text { Johnny.-Air, 'Take this cup of } \\
\text { sparkling wine' }\end{array}$ & $\begin{array}{l}\text { From the opera Lurline by William Vincent Wallace. } \\
\text { Lyrics by Edward Fitzball. }\end{array}$ \\
\hline $\begin{array}{l}\text { Duet.-Lucrezia and Alfonso.- Air } \\
\text { from Fra Diavolo. }\end{array}$ & (Auber) The particular number is not specified. \\
\hline
\end{tabular}

95 The lyrics are held in the Bodleian's Broadside Ballads Online Collection:

http://ballads.bodleian.ox.ac.uk/view/sheet/9426 [accessed 23/o2/2016]. 


\begin{tabular}{|l|l|}
\hline $\begin{array}{l}\text { [Changes to] } \\
\text { Air, 'Diddle cum do' }\end{array}$ & Unidentified \\
\hline $\begin{array}{l}\text { Song-Lucrezia. Original Air, F. } \\
\text { Kingsbury. }\end{array}$ & $\begin{array}{l}\text { F. Kingsbury was the arranger of music for the } \\
\text { burlesque. }\end{array}$ \\
\hline Song-Johnny Raw.- Air, 'Beviamo' & 'Tocchiamo, beviamo' from Rossini's La gazza ladra. \\
\hline $\begin{array}{l}\text { Song-Orsini-Air, 'The Glorious } \\
\text { Vintage of Champagne' }\end{array}$ & From Satanella, opera by M. W. Balfe \\
\hline $\begin{array}{l}\text { Chorus without sings 'Doodle dam' } \\
\text { [sic] of 'Ratcatchers [sic] Daughter' }\end{array}$ & Song made famous by Sam Cowell.96 \\
\hline $\begin{array}{l}\text { Song.-Johnny.-Air, 'The Glorious } \\
\text { Vintage of Champagne' }\end{array}$ & From Satanella, opera by M. W. Balfe \\
\hline Song-Johnny. Air, 'Madre se ognor' & Lucrezia Borgia \\
\hline $\begin{array}{l}\text { Finale.-Air, 'Medley from Lucrezia } \\
\text { Borgia' }\end{array}$ & Lucrezia Borgia \\
\hline
\end{tabular}

The way in which operatic numbers were treated in the burlesque was similar to how continental opera had been presented in London playhouses earlier in the century. The second half of the nineteenth century saw increased sensitivity to the composer's wishes and fidelity to the score, ${ }^{97}$ while in the first three decades of the century adaptations of continental opera routinely made significant cuts, simplifications and interpolations of new numbers..$^{8}$ Italian opera was translated into English for performance at the playhouse at Covent Garden. This often involved a complete restructuring of the original opera, and alteration of the vocal parts to accommodate the new English lyrics. When operas were performed in Italian the transformation was less drastic, but there were still significant modifications of vocal parts to suit the

\footnotetext{
${ }^{96}$ The lyrics are available here: http://monologues.co.uk/musichall/Songs-R/Ratcatchers-Daughter.htm [accessed 23/02/2016]

${ }_{97}$ Christina Fuhrmann positions the success of Der Freischütz in 1824 as a crucial event, highlighting the rhetoric of fidelity in criticism, and the success of Henry Bishop's 'faithful' Drury Lane production. See Christina Fuhrmann, 'Continental Opera Englished, English Opera Continentalized: Der Freischütz in London, 1824', Nineteenth-Century Music Review 1 (2004), 115-142. Rachel Cowgill has noted a similar shift towards 'fidelity' and a work-oriented approach in London productions of Mozart operas, but has placed the production of Don Giovanni at London's King's Theatre as marking 'a decisive swing toward work-oriented operatic values.' These values were shared first by critics and then audiences. See Rachel Cowgill, 'Mozart Productions and the Emergence of Werktreue at London's Italian Opera House, 178o1830', in Operatic Migrations: Transforming Works and Crossing Boundaries ed. Roberta Montemorra Marvin and Downing A. Thomas (Aldershot, 2006), 145-186. Lydia Goehr's, The Imaginary Museum of Musical Works: an Essay in the Philosophy of Music (Oxford, 1992) is a classic text on the development of the concept of an authoritative and authentic 'musical work', but applying Goehr's 'work concept' to opera is problematic. Operas are the product of multiple authors, combine different mediums, and often exist in several contrasting versions. The role of performers coupled with practical performance and staging issues present further complications. Roger Parker has discussed some of these issues and has examined ways in which a number of canonical operas have changed and been revised by composers and other authorial voices, challenging the notion of an authentic version or text. See Remaking the Song: Operatic Visions and Revisions from Handel to Berio (Berkeley, 200o). ${ }_{98}^{8}$ See Furhmann, Foreign Opera at the London Playhouses: From Mozart to Bellini (Cambridge, 2015) 138 for an overview of how operas were adapted at London playhouses.
} 
capabilities of the singers and simplifications of complex numbers. ${ }^{99}$ Simplicity and practicality were guiding principles: subplots were cut to simplify the action and reduce the running time, and new scenes or numbers were inserted, including arias that suited the capabilities of the singers. ${ }^{100}$ It was also common to interpolate numbers from the same composer's back catalogue. ${ }^{101}$ The use of interpolated music from other Italian operas in the burlesque may have been considered appropriate in retaining stylistic congruity, while the inclusion of English ballads also conformed to the standard pattern of opera adaptations earlier in the century. ${ }^{102}$

In both English and Italian adaptations, recitative was often curtailed because it was deemed boring by audiences. Dialogue moved the action along, while musical numbers were used to reflect on events and emotions. Catchy choruses and simple melodies were retained, while complex harmony, music that was wedded to action, and complicated, lengthy, and dramatic ensemble numbers were cut. Similarly, in Lucrezia Borgia! the operatic numbers retained in the burlesque were taken from lyrical arias or duets. Generally, choruses conveying action were removed: the burlesque opened with a popular solo ballad for Orsini rather than the opening number of the opera ('Nella fatal di Rimini e memorabil guerra') in which Orsini narrates how he was warned by an old man that Lucrezia Borgia would kill him and Gennaro to dramatic interjections by the chorus. The chorus that closes the scene, in which Gennaro's friends recognise Lucrezia Borgia and accuse her of killing members of their families, was also removed. Instead, Lucrezia's crimes (of giving bad investment advice) were narrated in spoken dialogue.

The removal of music wedded to action and of dramatic ensembles created a separation of music and dramatic development that was typical of English opera in the first three decades of the nineteenth century. Solo numbers, reflecting on and embellishing the action, rather than driving it, dominated English opera, but even they were often 'pruned to their briefest, most melodic moments'. ${ }^{103}$ Similarly, the operatic numbers included in the burlesque had relatively simple and easily memorable melodies. They were also substantially curtailed: often to only a couple of phrases from the original number. For example, only the first two phrases of Lucrezia's aria 'Com'è bello' were used. The more complicated, virtuosic sections of the aria were not included. The same is true of the treatment of the interpolated 'Guerra, guerra!' from Norma. The introductory dialogue between the soloist and chorus and the recitative were excised. Only the most memorable part of the chorus (the 8-bar phrase from the Allegroferoce) was retained.

Lucrezia Borgia! also included some English opera. This strongly suggests that the imagined audience was middle class, even if in reality it may have been more diverse;

\footnotetext{
99 Dideriksen, 'Repertory and Rivalry', 286-7.

${ }^{100}$ Dideriksen, 'Repertory and Rivalry', 286-343.

${ }^{101}$ Fuhrmann, Foreign Opera at the London Playhouses, 10.

${ }^{102}$ Fuhrmann, Foreign Opera at the London Playhouses, 31-3 and 122. Ballads were highly popular and represented the backbone of English opera. See George Biddlecombe, English Opera from 1834 to 1864 with Particular Reference to the Works of Michael Balfe (New York and London, 1994), 36-43 for an overview of the role and style of the ballad in English opera.

${ }^{103}$ Christina Fuhrmann, 'Scott Repatriated? La Dame Blanche Crosses the Channel', Gillen Wood, ed., volume on 'Romanticism and Opera', Romantic Circles Praxis Series (2005), 13. Available online: https://www.rc.umd.edu/praxis/opera/fuhrmann/fuhrmann.html [accessed 21/o8/15].
} 
English opera had never won the approval of the aristocracy, but its use of the English language and its simple, strophic songs were enjoyed by the bourgeoisie. ${ }^{104}$ Indeed, George Biddlecombe has found that advertisements in opera librettos at theatres offering English opera and English adaptations of continental opera were 'aimed at a range of middle-class families, from those whose incomes might direct them towards ready-made clothes rather than the more expensive hand-made dresses and suits, to others who could enjoy more expensive luxuries, such as imported wines, and the services of eminent doctors'. ${ }^{105}$ 'Take this cup of sparkling wine', from William Vincent Wallace's Lurline would have been an apposite choice for a predominantly middleclass audience. Lurline was currently enjoying a successful first run at Covent Garden as part of an English Opera season and received much press attention across conservative and liberal newspapers, which all attested to its popular and critical success. ${ }^{106}$ 'Take this cup of sparkling wine' was one of the opera's most popular numbers and was encored in February performances. ${ }^{107}$ Clearly the arranger intended to capitalise on current operatic hits.

Certainly, Lucrezia Borgia! did contain some numbers from popular genres, including some ballads (the great bourgeois drawing-room favourite, M. W. Balfe, was represented with his 'Glorious vintage of champagne' from Satanella), minstrel songs and music hall songs. Importantly, rather than questioning cultural hierarchies, the pairings of opera and popular music in Lucrezia Borgia! seem to have been made to reduce potential incongruity. For example, the burlesque included a clever transition from 'Com'è bello' from the original opera into Stephen Foster's parlour song, 'Come where my love lies dreaming'. This transition does not seem to have been effected in order to appeal to the lower orders of the audience. Indeed, the song's style has been compared to Italian opera. ${ }^{108}$ Susan Key argues that Stephen Foster's sentimental songs 'occupied a place defined by neither the "popular" nor "elite" song'. ${ }^{109}$ Such parlour ballads were performed by the middle classes and their subject matter took a bourgeois stance. ${ }^{110}$ As such, parlour ballads were intimately associated with bourgeois respectability. The discerning listener may have enjoyed the two numbers' similarities: the melodic arch, lyrical style, and mood of bittersweet sentimentality. The lyrics to 'Come where my love lies dreaming' also mirror the subject matter of 'Com'è bello':

\footnotetext{
${ }^{104}$ Derek Scott, The Singing Bourgeois: Songs of the Victorian Drawing-Room and Parlour (Milton Keynes, 1988), 16.

105 Biddlecombe, English Opera, 5.

106 'Royal English Opera, Covent Garden', The Morning Chronicle, 19 March 186o. The success of the opera was also mentioned in 'Royal English Opera', The Standard, 24 February 1860, 7. The Standard was financially dependent on the conservative party and was aimed at artisans and small tradesmen. See Brown, Victorian News and Newspapers, 62-3.

107 'Drama, Music \&c.' Reynolds's Newspaper, 26 February 1860. Reynolds's was a highly popular paper and enjoyed massive circulation. It carried miscellaneous popular and entertainment features, and dramatic crime reporting. It was Liberal-Radical in its politics. See Brown, Victorian News and Newspapers, 66 and 96.

${ }^{108}$ Susan Key, 'Sound and Sentimentality: Nostalgia in the Songs of Stephen Foster', American Music, 13, 2 (1995), 145-166 (145).

109 Key, 'Sound and Sentimentality', 147.

110 They often dealt with moral or spiritual concerns, attempting to educate audiences. Scott, Sounds of the Metropolis, 65-69.
} 
gazing at a loved one while they sleep. The two pieces juxtaposed in this instance maintained consistency of style and meaning.

It is also important to consider the influence of the arrangements on how popular music in burlesques would have been received. One reviewer found that the arranger, a Mr Kingsbury, had created stylistic consistency between the different types of music included:

The burlesque abounds with well-written parodies, the music to which has been arranged and composed by Mr. Kingsbury, and certainly few works of this class can boast of a better selection. Bearing in mind that the piece is a travestie upon an opera, Mr. Kingsbury has in the most artistic manner given an operatic complexion to the music, and the burlesque is full of concerted pieces and choruses which are attractive in themselves. ${ }^{111}$

Unfortunately a score does not exist for this burlesque, but these comments suggest that Kingsbury's arrangements added refinement to the popular and minstrel tunes. The phrase 'operatic complexion' suggests that he may have smoothed out stylistic contrasts with the operatic numbers, perhaps through alterations of tempo and scoring, writing orchestral rather than banjo or piano accompaniments, and through creating sustained, lyrical legato lines. Such arrangements were common in British minstrel performances at the time anyway. In Britain, minstrel troupes stressed the wholesomeness and respectability of their shows in order to court the bourgeoisie, in contrast to their American counterparts who were popular with the urban working classes. ${ }^{112}$ Minstrel shows were associated with refinement, far more so than music hall, for example. ${ }^{113}$ Studies of minstrelsy lack specificity in defining audiences. Nonetheless, Michael Pickering's work on British minstrelsy highlights the middleclass elements of minstrel shows. While Pickering acknowledges the cross-class appeal of the genre, he focusses on its development towards greater refinement. He also mentions the 'bourgeois values' evident in minstrel song lyrics. He emphasises that minstrelsy was accessible in a range of venues, which would suggest that the crossclass appeal was due to the flexibility of the shows. ${ }^{114}$ Indeed, he argues that there were different 'strains of minstrelsy', which were socially distinct from one another and appealed to different sectors of society. ${ }^{115}$

It is highly likely that the majority of the St James's Theatre audience would have attended the genteel, bourgeois variety of minstrel shows, as troupes performed regularly at the theatre in the 1840 on and 1850 . ${ }^{116}$ From the 1840 such minstrel shows offered musical accompaniments of harmonic complexity, a heterogeneous mixture of

\footnotetext{
${ }^{11}$ The Standard, 10 April 1860, 2.

${ }^{112}$ Derek Scott, 'Blackface Minstrels, Black Minstrels, and their Reception in England', in Europe, Empire, and Spectacle in Nineteenth-Century British Music, ed. Rachel Cowgill and Julian Rushton (Aldershot, 2006).

${ }^{113}$ Michael Pickering, Blackface Minstrelsy in Britain (Aldershot, 2008), 5.

${ }^{114}$ Pickering, Blackface Minstrelsy in Britain, 40.

${ }^{115}$ Michael Pickering, 'Fun Without Vulgarity? Commodity Racism and the Promotion of Blackface Fantasies', in Colonial Advertising E Commodity Racism ed. Wulf D. Hund, Michael Pickering, Anandi Ramamurthy (Zürich and Münster, 2013), 134.

${ }^{16}$ See Duncan, The St James's Theatre, Chapter 3: The French, the Magicians, the Ethiopians under John Mitchell 1842-1854.
} 
music, and often ended with an opera burlesque. ${ }^{117}$ Troupes also put greater emphasis on sentimentalism, and gained a reputation for 'wholesome family entertainment'. ${ }^{18}$ The minstrel shows at the St. James's Theatre emphasised 'elegance, refinement, and grand-scale display'. ${ }^{119}$ It is unlikely, therefore, that the inclusion of minstrel songs in burlesque encouraged greater audience diversity, as there was actually an overlap between opera's audiences and minstrelsy's audiences. Indeed, expensive sheet music prices suggest that minstrel songs were performed in middle- and upper-class homes. ${ }^{120}$ The trends in minstrel performances in Britain at the time, and at the St James's Theatre in particular, provide further evidence that the minstrel songs (and any other popular songs) included in the production were given in a refined arrangement. Orchestral arrangements would reduce any sense of deliberate disjunction between opera and minstrelsy, but equally minstrelsy may not have been considered a 'low' genre in this context anyway.

Lucrezia Borgia! had been transformed into a play with a series tunes popular with the bourgeoisie and memorable operatic excerpts. The treatment of Italian opera in the burlesque offered an accessible style of opera production that had been popular with the middle classes before the more recent interest in fidelity to the score. Burlesque remained free from the constraints of more 'serious' opera productions, retaining the ability to satisfy audience's tastes for Italian opera's 'greatest hits', without requiring the stamina needed to attend a sustained performance. Unfortunately, the gap between this imagined audience, who enjoyed refined minstrelsy and English and Italian opera (at least its greatest hits in adaptation and translation), and the reality of the theatre's current audience was quite large. The writer and arranger had not responded to the theatre's current state of transition. A reviewer drew attention to the problem that:

In selecting the opera of Lucrezia Borgia as a subject for burlesque, Mr. Leicester Buckingham has not been particularly happy, as the lyric work is not sufficiently well known to the habitués of those great supports of a theatre, the pit and gallery, to enable them to appreciate the travestie; consequently, much of the point and fun passes unappreciated. ${ }^{121}$

The reviewer went on to suggest that with some revision the production would be 'specially acceptable to the occupants of the stalls and boxes'. ${ }^{122}$ Clearly, Buckingham and Kingsbury had not considered Chatterton's recent strategy of trying to attract a new audience with lower prices and accessible repertoire and had planned the production with only a small sector of the actual audience in mind. The stylistic uniformity of the music and the close relationship between the burlesque and the original opera prevented it from being a commercial success; its consumer market was too narrow. Burlesques later in the decade retained this focus on the bourgeois market, but they became more commercially savvy, and relied less on the audience's prior knowledge of opera.

\footnotetext{
${ }^{117}$ Pickering, Blackface Minstrelsy in Britain, 17-18.

${ }^{118}$ Pickering, 'Fun Without Vulgarity?' 130-4.

119 Pickering, 'Fun Without Vulgarity?' 138.

${ }^{120}$ Pickering, 'Fun Without Vulgarity?' 133.

${ }^{121}$ The Standard, 10 April 1860, 2.

${ }^{122}$ The Standard, 10 April 186o, 2.
} 
Little Don Giovanni was performed at the Prince of Wales's Theatre on 21 December 1865. The date is significant because the theatre had recently reopened under the new management of Marie Wilton following extensive refurbishment. Before this time, the theatre had been called the Queen's Theatre. An examination of playbills shows that in the 1850 os the Queen's Theatre tended to show pantomime and popular sensational melodrama about supernatural themes, exotic subjects, and murder, such as Zarah the Gipsy Girl performed 20 June $1855 .{ }^{123}$ The repertoire at the Queen's drew the attention of the examiner of plays. Donne objected to the sensational themes of crime and murder displayed in melodramas like Zarah and also criticised the poor ventilation of the theatre, calling it a 'dust hole'. ${ }^{124}$ Ticket prices around this time were low. In 1855 admittance to the pit cost sixpence and the most expensive seats were the boxes at 2 shillings and sixpence. ${ }^{125}$ The theatre was catering for a local working- and lowermiddle-class audience.

Davis and Emeljanow have argued that the transformation of the Queen's Theatre did not occur overnight, and had actually begun before Marie Wilton's involvement. ${ }^{126}$ Either way, at the time of the Little Don Giovanni production the Prince of Wales's was known as a fashionable and respectable theatre. The reopening was commented on in the press, reviews noting the high ticket prices, the opulent décor and the fashionable audience:

The most stirring event of the season came off on Saturday. We allude to the opening, by Mr Byron and Miss Marie Wilton, of the little theatre in Tottenham street, under the appellation of "The Prince of Wales's" [...] For the last twenty-six years it has been under the management of $\mathrm{Mr} \mathrm{C}$ James, a scenic artist, who now has called in to his aid Mr Byron and Miss Wilton. The experiment is likely to answer well. The doors were literally besieged, and admission was scarcely possible. The prices are, however, on an aristocratic scale, and many carriages were among the crowd assembled at the doors. The interior of the house has been entirely reconstructed and richly decorated ${ }^{127}$

Reporters admired the new interior design, describing the white and gold trellis on the boxes, the gold stars on the ceiling, the white enamelled scroll and the Prince of Wales's feathers framing the proscenium arch, the ornamental stand of flowers on each side of the arch, and the comfortable cushioned seating of the stalls and boxes. ${ }^{128}$ Such attention to decoration was important in achieving middle-class respectability; Hugh Maguire has argued that the interior décor of West End theatres in the second

\footnotetext{
${ }_{123}$ Playbill for Zarah the Gypsy Girl, 20 June 1855, 'Theatre Box: Queen's Theatre 1855-8', VEA.

${ }^{124}$ Davis and Emeljanow, Reflecting the Audience, 142.

${ }^{125}$ Playbill for Zarah the Gypsy Girl, 20 June 1855, 'Theatre Box: Queen's Theatre 1855-8', VEA.

${ }^{126}$ Davis and Emeljanow, Reflecting the Audience, 154.

${ }^{127}$ Unlabelled newspaper cutting dated 22 April 1865, 'Theatre Box: Prince of Wales's Theatre 1865', VEA

[Date added post hoc].

${ }^{128}$ Unlabelled newspaper cutting dated 22 April 1865, 'Theatre Box: Prince of Wales's Theatre 1865', VEA

[Date added post hoc].
} 
half of the century mirrored the interior of middle-class homes, offering intimacy, comfort and respectability. ${ }^{129}$

The new ornately decorated theatre attracted a new type of audience. Playgoers began to wear evening dress, and royalty, including the Prince of Wales himself, occasionally attended. The Little Don Giovanni premiere took place eight months after the reopening. The majority of the audience would have comprised the professional middle class, including writers, surgeons, politicians and lawyers. ${ }^{130}$ Some of the old Queen's audience would still have attended, but many of them dispersed across the West End. ${ }^{131}$ Ticket prices, described as 'aristocratic' in the press, were now significantly higher than in the days of the Queen's Theatre, ranging from $£ 22 \mathrm{~s}$ to $6 \mathrm{~d}$ (see Appendix Table 2).

We have seen that the timing of the Little Don Giovanni production also coincided with a period of renewed confidence in the theatre, with new theatres being built across the West End. The Prince of Wales's management capitalised on the growing reputation of the West End as a tourist destination, using a number of strategies to commercialise their burlesque productions. Marie Wilton and her husband, Squire Bancroft, cultivated their celebrity and were the subjects of newspaper columns. ${ }^{132}$ Marie Wilton was a burlesque actress as well as manageress, and she cast herself as the title role in Little Don Giovanni. ${ }^{133}$ Her involvement was noted in the press, helping to puff the performances.

West End retailers and theatre managers alike believed that shoppers and audiences had a heightened taste for the spectacular and the visual. ${ }^{134}$ The Little Don Giovanni burlesque capitalised on this commercial demand for theatrical spectacle. ${ }^{135}$ The production involved several complicated scene changes from exotic Spain to familiar London, using common strategies of commercial theatre of the time to attract tourists through 'affirming the accessibility of a different world or celebrating the materiality of the familiar world'. ${ }^{136}$ The spectacular scenery was commented on frequently in press reviews, which admired how the audience was 'suddenly brought before a charming picture of a Spanish Vineyard, by Sunset, which so delighted the audience that a general summons called the clever artist, Mr Charles S James, before them.' ${ }^{137}$ The final scene was emphasised on the playbill and involved a transformation from Leicester Square to the 'Winter Garden of the Christmas Fairies'. This was highly praised in reviews, which enthused that 'The transformation scene of a most magnificent character takes place, brilliantly illuminated with the magnesium and

\footnotetext{
129 Maguire, 'The Victorian Theatre as a Home from Home...', 107-121.

${ }^{130}$ Davis and Emeljanow, Reflecting the Audience, 155-7.

${ }^{131}$ Davis and Emeljanow, Reflecting the Audience, 158.

${ }^{132}$ For a substantial feature on Bancroft see 'Men and Women of the Day', The Hornet 18 December 1878 ,

'Theatre Box: Prince of Wales's Theatre 1865, VEA.

${ }^{133}$ It was common at the time for women to be cast as the lead role in burlesques of Don Giovanni. See

Cowgill, 'Re-Gendering the Libertine', 45-66 for details.

134 Rappaport, Shopping for Pleasure, 189.

135 See Michael R. Booth, Victorian Spectacular Theatre (Boston, London and Henley, 1981), for a

thorough examination of spectacle in popular Victorian theatre.

${ }^{136}$ Davis and Emeljanow, Reflecting the Audience, 174.

137 'Boxing Night at the Theatres', The Era, 31 December 1865.
} 
other lights, producing a wonderful stage effect.'138 The producer and scene painter paid particular attention to scenery, painting and effects, having learnt from the longstanding enthusiasm of tourists for exotica, technology and spectacle, which, as we have seen, had reached new heights at the ${ }^{1851}$ Great Exhibition. The use of magnesium to create special effects would have been unusual at the time, further suggesting that James intended to provide his audience with novelties in technology. 139 The scene with the statue of the Commendatore was set in a square that put reviewers in mind of a Spanish Square and London's own Leicester Square simultaneously (see Plate 1). This mingling of Spain and London coupled with the transformation into the fairy garden gave audiences a spectacle that rendered the familiar exotic and magical, and that also gave the burlesque a pantomime feel that was appropriate for the festive audience.

\section{Plate 1: 'A Spanish Square' from Little Don Giovanni ${ }^{140}$}

The Prince of Wales's burlesque producers were also mindful of making their musical choices commercially appealing. Given that Don Giovanni was a favourite of middleclass audiences, ${ }^{141}$ we might expect the burlesque to retain a considerable amount of music from the original opera. Some of the original music was incorporated, but the overall programme suggests that the management was more interested in creating variety than capitalising on Mozart's popularity. This mirrored strategies of large department stores, such as William Whiteley's Universal Provider, which offered diverse commodities and services in order to cater to a new heterogeneous, mass public that was nonetheless essentially middle-class. ${ }^{142}$ Similarly, the music in Little Don Giovanni included a diverse mixture of operatic music, parlour songs, traditional songs, minstrel songs and music hall songs (see Table 2). The Little Don Giovanni production was a great success, prompting many favourable reviews, a long run, and even the patronage of the Prince of Wales at one of the performances. ${ }^{143}$ The management understood that its middle-class audience comprised a fluid, ambiguous, heterogeneous group of people. The emphasis on variety created a result closer to ballad opera than the musical selections of Lucrezia Borgia!

\footnotetext{
138 'Multiple Arts and Popular Culture Items', The Standard, 27 December 1865, 2.

139 Magnesium started to be mass produced in 1866 and the burning of magnesium powder to create stage effects only became widespread in the 188 os. See Terence Rees, Theatre Lighting in the Age of Gas (London, 1978), 78-9 and 145 .

140 (C) Victoria and Albert Museum, London. Reproduced with permission.

${ }^{141}$ Hall-Witt positions the complete staged premiere of Don Giovanni in London in 1817 as a turning point for middle class audiences entering the opera house. See Jennifer Hall-Witt, Fashionable Acts: Opera and Elite Culture in London 1780-188o (Hanover and London, 2007), 146-147. See also Rachel Cowgill, "Wise Men from the East”: Mozart' Operas and their Advocates in Early Nineteenth-Century London', Music and British Culture, 1785-1914: Essays in Honour of Cyril Ehrlich (Oxford, 2000), 39-64. Although the staged premiere of Don Giovanni was slow to take place for a number of practical issues, much of the opera had been heard in different contexts, including isolated numbers that were inserted into pasticcios and comic operas, in mixed concert programmes, and in private stagings. See Rachel Cowgill, 'Mozart's Music in London, 1764-1829: Aspects of Reception and Canonicity', Ph.D. diss (King's College London, 2000), 140-193.

${ }^{142}$ Rappaport, Shopping for Pleasure, 18.

143 'Coursing', Sporting Gazette, Limited, 10 February 1866, 95.
} 
Table 2: Music in Little Don Giovanni

\begin{tabular}{|c|c|}
\hline Title & Origin \\
\hline 'Literary Dustman’ & $\begin{array}{l}\text { Music Hall song based on a morris tune. Original lyrics by } \\
\text { Robert Glindon c. } 1832\end{array}$ \\
\hline $\begin{array}{l}\text { 'Operatic symphony' } \\
\text { (unidentified) leading to } \\
\text { Song.-Air, 'Paddle your own } \\
\text { canoe' }\end{array}$ & Traditional. Sung to the tune of Rosin the Bow. \\
\hline Duet-'My Pretty Page' & Ballad c. 1828-9. Author and composer unknown. \\
\hline Scena-'Di Quilla [sic] Pira’ & Il trovatore (Verdi) \\
\hline $\begin{array}{l}\text { Concerted Piece-Air, 'The } \\
\text { Pullback' }\end{array}$ & Minstrel song. ${ }^{144}$ \\
\hline Chorus, 'Giovanette [sic]' & ‘Giovinette, che fate all'amore’ from Don Giovanni (Mozart) \\
\hline Music-'Beauty of Brixton' & Ballad. Author and composer unknown. ${ }^{145}$ \\
\hline $\begin{array}{l}\text { Quintette.-'Early in the } \\
\text { Morning' }\end{array}$ & Minstrel song - 'So Early in de Morning' \\
\hline Quartette._'La [sic] ci darem' & 'Là ci darem la mano' from Don Giovanni \\
\hline Air, 'Tapioca' & Minstrel song by E. Warden \\
\hline Trio._-'The Telegraph’ & $\begin{array}{l}\text { Music Hall Song called 'The Telegraph Girl' written and } \\
\text { composed by George Leybourne and Alfred Lee. Performed } \\
\text { by George Leybourne. }\end{array}$ \\
\hline $\begin{array}{l}\text { Concerted piece- 'Les deux } \\
\text { Ajax' from La Belle Hélène }\end{array}$ & $\begin{array}{l}\text { This refers to 'Voici les rois de la Grèce' from Offenbach's La } \\
\text { Belle Hélène }\end{array}$ \\
\hline Finale._'Rally' & Unidentified. \\
\hline $\begin{array}{l}\text { Concerted piece.-Air, 'Tootle } \\
\text { Tum Tay' }\end{array}$ & $\begin{array}{l}\text { The similarity of the lyrics suggests that this refers to Arthur } \\
\text { Lloyd's 'I vowed I never would leave her' (Music Hall Song). } \\
\text { It was originally by George Christy and sung by the Christy } \\
\text { Minstrels. }\end{array}$ \\
\hline $\begin{array}{l}\text { Music (bit of 'Aunt Sally' } \\
\text { unison). }\end{array}$ & Minstrel Song - 'My old aunt Sally' \\
\hline $\begin{array}{l}\text { Concerted piece.-`The } \\
\text { Postman' }\end{array}$ & $\begin{array}{l}\text { Lyrics suggest that this refers to 'The Postman's Knock', } \\
\text { lyrics by L. M. Thorton, music by W. T. Wrighton c. 186o. } \\
\text { Popular parlour ballad. }\end{array}$ \\
\hline
\end{tabular}

${ }^{144}$ Lyrics available through the Bodleian's Broadside Ballads Online:

http://ballads.bodleian.ox.ac.uk/static/images/sheets/05000/04978.gif) [accessed 23/02/2016].

${ }^{145}$ Lyrics available through the Bodleian's Broadside Ballads Online:

http://ballads.bodleian.ox.ac.uk/view/sheet/16009 [accessed 23/02/2016]. 


\begin{tabular}{|l|l|}
\hline Music, 'Opera' & $\begin{array}{l}\text { Don Giovanni. The dialogue suggests the intended music } \\
\text { was from the Commendatore scene. }\end{array}$ \\
\hline Finale-'Early in the morning' & Minstrel song - 'So Early in de Morning' \\
\hline
\end{tabular}

The bourgeois audience may have been heterogeneous, but some pastimes, particularly domestic music-making, were popular across the middle classes. The arranger of the burlesque's music capitalised on the bourgeois taste for commercial stand-alone ballads that could be bought and played at home. Drawing-room ballads were particularly popular with middle-class women who were wealthy enough to have servants to care for their houses and children. Consequently, they had leisure time to devote to singing and playing the piano. ${ }^{146}$ The music in the burlesque drew on the expectation that its audiences would own a piano. Indeed, ownership of a piano cut across middle-class society, whether a family's income fell towards the lower or higher end of the spectrum, as virtually every respectable family owned a piano by the 1870s. ${ }^{147}$ It symbolised 'respectability, achievement and status'. ${ }^{148}$ Piano ownership became increasingly possible across the middle classes as wages and living standards rose in the second half of the century and pianos in a range of prices became available. Some working-class people, such as respectable artisans, were able to hire pianos on credit, but the practice was disapproved by the higher orders out of snobbery and distrust of the system. The majority of the musical numbers shown in tables 5,6 , and 7 could be purchased as sheet music. Don Giovanni offered the greatest mixture of genres. Tellingly, these genres represented the diverse sources from which bourgeois Victorian drawing-room and parlour ballads were drawn. ${ }^{149}$ Reviews suggest that the Prince of Wales's management had found a commercially viable musical format (which they repeated in other burlesques); a reviewer for Bell's Life in London and Sporting Chronicle enthused about 'the selected music of that pattern which is so popular now-a-days'. ${ }^{150}$ The key was variety, but variety within bourgeois limits.

As in Lucrezia Borgia! the popular genres were 'bourgeoisified'. The minstrel songs chosen were already firm favourites which the bourgeoisie would sing in their own homes. For example, Little Don Giovanni included a 'Quintette' called 'Early in the Morning' - an adaptation of the minstrel song 'So Early in de Morning'. This song was published in an expensive collection (priced 2 shillings), entitled Popular Plantation Songs, which was aimed at a wealthy, genteel market. ${ }^{11}$ We know that the meanings and functions of minstrel songs, even the same song, could change quite considerably depending on the setting in which it was performed and the particular arrangement. (Indeed, 'So Early in de Morning' was also a favourite of working-class singers and labourers.) The meanings of the song in this case were contingent on its performance context alongside opera and drawing-room ballads, shorn of dialect, provided with

\footnotetext{
${ }^{146}$ Scott, The Singing Bourgeois, 60-3.

147 See Cyril Ehrlich, The Piano: A History (London, 1976), 92-98.

${ }^{148}$ See Ehrlich, The Piano, 97. Social and economic factors converged to make the piano a desirable and affordable commodity for every respectable home.

${ }^{149}$ For an overview of the genres that were performed in the drawing room see Scott, The Singing

Bourgeois, Chapter 1: 'The Foundations of the Drawing-room Genre', 1-44.

150 'Music and the Drama', Bell's Life in London and Sporting Chronicle, 30 December 1865, 3.

${ }^{151}$ See Pickering, 'Fun Without Vulgarity?' 135 for details.
} 
new lyrics, and performed in a bourgeois theatre, probably to an orchestral accompaniment. The middle-class familiarity with minstrel music likely meant that any interpolations had long lost their subversive effects. ${ }^{152}$

Music hall was another question. Dagmar Höher has shown that before 1890 the vast majority of London music halls were frequented by working-class and lower-middleclass audiences. ${ }^{153}$ The traditional narrative of music hall's development describes a transition towards greater respectability and a more middle-class audience. 1890 is given as a key date, at which point music hall owners and managers directly targeted the middle classes by trying to clean up the halls. They offered respectable entertainment, policed audience behaviour, and began to distance music hall from its traditional links to tavern culture, aligning it more closely with the theatre. However, Höher has argued that even then bourgeois attitudes were conflicted and there were still many anti-music hall campaigns. ${ }^{154}$ Middle-class audiences may have enjoyed blackface minstrelsy, but (certainly in the 186os), they were far less accepting of music hall. They objected to its adverse effects on working-class morals, ${ }^{155}$ its lack of respect for middle-class values of temperance and hard work, ${ }^{156}$ and the apparent tolerance of prostitutes in the halls. ${ }^{157}$

Mid-Victorian burlesques occasionally included music hall songs in their programmes, but even then, they were far outnumbered by other genres. Lucrezia Borgia! included only two music hall songs, Little Don Giovanni three, and Robert the Devil none (see Tables 1, 2 and 3). The songs are by some of the most famous performers in music hall history: Sam Collins, Sam Cowell, George Leybourne and Arthur Lloyd. Their ubiquity meant that they would have been familiar even to those members of the audience who would not have wanted to be seen at a music hall. Interestingly, the music hall songs in Little Don Giovanni were closely associated with the figure of the buffoon policeman who is set on catching Don Giovanni throughout the burlesque. ${ }^{158}$ The sergeant first appears dancing to Robert Glindon's the 'Literary Dustman', lamenting that Don Giovanni has eluded him. Arthur Lloyd's 'I vowed I never would leave her' was also sung by the sergeant along with peasants Masetto and Zerlina and a chorus of peasant girls. In these cases music hall helped to characterise lower-class characters, highlighting difference rather than placing 'high' and 'low' culture on a similar level.

\footnotetext{
${ }^{152}$ The ways in which minstrelsy was received have been of interest to scholars. Wiliam J. Mahar has suggested that 'non-plantation elements' of minstrel shows, particularly burlesque humour, were often central to their appeal. See William J. Mahar, Behind the Burnt Cork Mask: Early Blackface Minstrelsy and Antebellum American Popular Culture (Urbana, 1999). For an overview of developments in minstrelsy scholarship see Philip F. Gura, 'Review: America's Minstrel Daze', The New England Quarterly 27 (1999), 602-616.

153 Dagmar Höher, 'The Composition of Music Hall Audiences, 1850-190o', in Music Hall: The Business of Pleasure ed. Peter Bailey (Milton Keynes, 1986), 76.

${ }^{154}$ Höher, 'The Composition of Music Hall Audiences', 85-7.

${ }^{155}$ Dagmar Kift, The Victorian Music Hall: Culture, Class and Conflict (Cambridge, 1996), 77.

${ }^{156} \mathrm{Kift}$, The Victorian Music Hall, 99.

${ }^{157}$ Kift, The Victorian Music Hall, 136.

${ }^{158}$ The policeman provided a common figure of fun in Victorian popular culture, particularly in music hall. See Dave Russell, Popular Music in England 1840-1914: A Social History (Manchester, 1987), 101. For an examination of Victorian policemen's engagement with musical culture see Rachel Cowgill, 'On the Beat: the Victorian Policeman as Musician', in Music and Institutions in Nineteenth-Century Britain ed. Paul Rodmell (Farnham, 2012), 221-246.
} 
On another occasion, Sam Cowell's 'Ratcatcher's daughter' was heard outside a tavern in Lucrezia Borgia! The interpolation of a music hall song here simply serves to set the scene. All of this further suggests that, although burlesque did incorporate popular music, it mostly drew on popular music that was respectable and compatible with middle-class tastes.

The Prince of Wales's Theatre management also cleverly catered for differences within the bourgeois relationship to opera. A significant proportion of the middle classes were suspicious of opera's foreignness and would have felt uncomfortable attending an opera. 159 This suspicion is evident in the new lyrics provided for the minstrel song 'The Pullback', which was sung as an ensemble piece and ended with a roll call of operatic arias:

Anna. Oh, this behaviour is too bad!

Sergeant. Now, who am I to collar?

Giovan. You lead on to the station house;

My man and I will follow.

Lepor. Oh, isn't this a pullback!

All: Oh, yes, it was a pullback!

$\mathrm{Oh}$ - oh! heigho! O!

Lepor. A most decided pullback!

All: Oh - oh - heigho!

Giovan. Oh, what a pullback!

All: Oh, heigho! heigho! heigho!

Giovan. Una voce poco fa!

Anna. True, and ah che la morte!

Luce di quest anima.

Sergeant. A grand piano-forte !

Giovan. Di pecator [sic] ignobile.

Anna. Also vedrai carino!

Giovan. Likewise La Donna Mobile [sic]!

Lepor. And Signor Harri-Boleno ${ }^{160}$

The listing of famous arias in this way positions Italian, the language of opera, as a nonsense. The arias are divorced from meaning and listed amongst 'A grand pianoforte' and 'Signor Harri-Boleno', a famous Victorian clown, suggesting that these 'foreign-sounding' phrases are interchangeable with the aria titles. However, there were other members of the middle class who did attend opera and who saw knowledge of art traditionally associated with aristocratic tastes as a marker of respectability. Those of the audience who could recognise the titles of these arias and their origins in Il barbiere di Siviglia, Il trovatore, Linda di Chamounix, Lucrezia Borgia, Don Giovanni and Rigoletto would have felt self-congratulatory in their knowledge of a high-status cultural code, which they shared with others who also understood the

\footnotetext{
159 Scott, The Singing Bourgeois, 16 and 19.

${ }^{160}$ H.J. Byron, 'Little Don Giovanni, or Leporello and the Stone Statue', Add MS 53047, G L.C. Plays Dec. 1865, 9-9a, British Library.
} 
references. ${ }^{161}$ In this way, Little Don Giovanni appealed to different members of the heterogeneous middle-class audience, leaving the ambiguity of the middle-class selfdefinition unchallenged. Tellingly, only the higher-class characters, Don Giovanni and Donna Anna participate in the roll call; the sergeant and the servant, Leporello, are unable to join in the game.

\section{Creating a Niche: Robert the Devil at the Gaiety Theatre}

By the time of the production of Robert the Devil on the night of the opening of the new Gaiety theatre on 21 December 1868, the boom in theatre building was well under way, as was a 'process of commercialization and exclusiveness that would isolate the West End'. ${ }^{162}$ The Gaiety drew a similar bourgeois audience to the St James's and the Prince of Wales's, but there were also important differences in its clientele. Here the watchword was fashion. The opening night was an important event that received much press attention. The Times described the theatre as

producing an exceptional effect, with its broad balcony and spacious private boxes[...]The gorgeous character of the decorations, the exquisite taste of scenery and costumes in three new pieces, all denoted a fresh spirit of luxury making its way into theatrical arrangements of the capital. ${ }^{163}$

The spacious private boxes, the ornate interior decoration, and the elegant dress of the audience can be seen in an image of the Robert the Devil production (Plate 2):

\section{Plate 2: 'Robert the Devil', The Penny Illustrated Paper, 4 September $1869^{164}$}

The image published in The Penny Illustrated Paper highlights the spectacle of the occasion: the dancers on stage, the complicated set, and the lavish surroundings of the theatre itself. The audience is depicted wearing evening dresses and dinner jackets, and even the audience members in the pit and gallery have ornate hairstyles and jewellery and are smartly dressed. The image positions the Gaiety audience as an important part of a fashionable theatrical spectacle,

\footnotetext{
${ }^{161}$ Moody acknowledged that burlesque is a genre which 'flatters the cultural knowledge of genteel spectators', but this aspect of burlesque has received little scholarly interest. Moody, Illegitimate Theatre, 139.

${ }^{162}$ Davis and Emeljanow, Reflecting the Audience, 186.

163 The Times, 24 September 1868. Newspaper cutting 'Theatre Box: Gaiety 1868', VEA. The Morning Star (23 December 1868) also commented on the 'elegant lines' and 'rich ornamentation' of the theatre (Newspaper cutting 'Theatre Box: Gaiety 1868', VEA.)

${ }^{164}$ Reproduced with permission of Peter Joslin (Image from the Peter Joslin Collection). Interestingly, the Penny Illustrated Paper paid particular attention to literature and the arts. It targeted the working classes specifically with the aim of decreasing “intellectual and cultural inequalities" among the different social classes in imposing on its readership dominant ideas and cultural tastes'. See Michèle Martin, 'Conflicted Imaginaries: Victorian Illustrated Periodicals and the Franco-Prussian War (1870-71), Victorian Periodicals Review (2003), 41-58 (45). With this democratic aim in mind, it seems likely that the middle-class owners of the periodical believed that the Gaiety burlesque was a dominant cultural phenomenon that its readers should know about, and ideally participate in themselves. The coverage of the event in a working-class periodical may also suggest that even though the Gaiety audience was constructed as fashionable and upper-middle class, it may have been more diverse in reality.
} 
highlighting the visibility of the audience to itself. ${ }^{165}$ Gaiety prices were on a similar scale to those at the Prince of Wales's, except that they charged considerably higher prices for the pit and gallery (2s and is at the Gaiety, compared to is $6 \mathrm{~d}$ and $6 \mathrm{~d}$ at the Prince of Wales's), suggesting that they were trying to discourage the lower echelons of society (see Appendix table 3).

The manager of the Gaiety, John Hollingshead, apparently 'laboured under no delusion that he was there to elevate public taste and to educate'. ${ }^{166}$ A reporter from Fun noticed that the Gaiety 'seems to secure the support of the tribe which represents, if not intelligence, at least wealth'. ${ }^{167}$ The choices made for the Robert the Devil production suggest that the Gaiety management firmly understood that its fairly homogeneous, upper-middle-class audience wanted luxury, spectacle, fashion and frivolity rather than serious, educational drama.

The first full production of Robert le Diable in London, which was advertised as 'authentic', took place in 1832 at the King's Theatre. French operas at the time were routinely translated into English or Italian. Adaptations were often modified along similar lines to Italian opera, cutting complex ensemble numbers, dramatic music, and lengthy ballets. ${ }^{168}$ To some extent, these trends can be seen in the way Robert the Devil was presented at the Gaiety theatre. The only music from the original opera to be included was the opening drinking chorus ('Versez à tasse pleine'). The most memorable melodic part of the chorus was adapted as a solo air. On the libretto and playbill the title of this number was given in Italian, confirming that the audience were most likely to be familiar with the piece in an Italian version. The opera's dramatic music, including the music to the famous ballet of the nuns, was cut. Instead, the simple, memorable and repetitive chorus 'A fosco cielo' from Bellini's La Sonnambula took its place, perhaps reflecting the trend to translate grand opera into an accessible Italianate form.

Generally, however, Robert the Devil bore little resemblance to Italian opera or grand opera. The musical choices were fairly homogeneous: most of the music came from operetta and much of it from Offenbach. Unlike at the Prince of Wales's, the Gaiety management did not try to appeal to a diverse range of tastes within a heterogeneous middle-class audience. The musical choices were part of a different commercial strategy: the theatre was carving out a particular niche for itself in cornering the popular French operetta market, regularly producing operetta throughout the year with Offenbach a regular fixture. Interestingly, Gilbert's other burlesques written around the same time for other theatres, including Dr. Dulcamara or the Little Duck and the Great Quack (on Donizetti's L'elisir d'amore) for the St James's Theatre in 1867 and La Vivandière or True to the Corps (on Donizetti's La fille du régiment) for the Queen's Theatre in 1868, contained a far greater variety of ballads, operatic music, minstrel music and operetta on similar lines to the Prince of Wales's model. Gilbert

\footnotetext{
165 Davis has examined the intersection between theatrical painting and public opinion, arguing audiences 'realised that they too were part of the representation taking place within the theatrical space they inhabited'. See Davis, 'Spectatorship', 67.

${ }^{166}$ W. Macqueen Pope, Gaiety: Theatre of Enchantment (London, 1949), 87.

167 'Here, There, and Everywhere', Fun, 2 January 1869, 165.

${ }^{168}$ See Sarah Hibberd, 'Grand opera in Britain and the Americas', in The Cambridge Companion to Grand Opera ed. David Charlton (Cambridge, 2003), 403-422 (especially 404-411).
} 
altered his approach for the specific context of the Gaiety. In the manuscript of Robert the Devil submitted to the Examiner of Plays, many of the details of the music were missing, but suggestions have been pencilled in. ${ }^{169}$ These included a chorus to open the second scene at the Princess's Palace. No chorus appears in the published version at this point, but the manuscript suggested choruses from either 'Huguenots' or 'Grande Duchess'. A number from Offenbach's La Grande Duchesse de Gérolstein was eventually used as a finale to the burlesque. Other pencil markings suggested the use of 'Chateau [sic] de Ko-chout', 'Ile [sic] de Tulipatan' and 'Le Dieu et le Bayadère'. These suggestions were included in the published version of the burlesque (see Table 3 for details.) The suggested musical choices and the seeming interchangeability about where the chorus from Grande Duchesse should occur, suggest that the guiding principle in the musical choices was simply that the majority should come from French operetta.

\section{Table 3: Music in Robert the Devil}

\begin{tabular}{|l|l|}
\hline Title & Origin \\
\hline $\begin{array}{l}\text { Opening Chorus. 'Versiamo a } \\
\text { tuzza [sic] piena' }\end{array}$ & Opening Chorus, Robert le diable (Meyerbeer) \\
\hline Air changes to 'Al sol piacer' & Opening Chorus, Robert le diable. \\
\hline $\begin{array}{l}\text { Song. Raimbault. Air -'Les } \\
\text { Rendezvous de noble } \\
\text { compagnie' }\end{array}$ & Ferdinand Hérold, Le Pré aux Clercs. \\
\hline $\begin{array}{l}\text { Concerted Piece.-Trio, } \\
\text { Robert, Raimbault, Bertram, } \\
\text { and others. Air-'La } \\
\text { tremenda ultrice spada' }\end{array}$ & Bellini, I Capuleti e i Montecchi \\
\hline $\begin{array}{l}\text { Air changes to-'Hunting the } \\
\text { Hare' }\end{array}$ & Welsh Folksong. \\
\hline $\begin{array}{l}\text { Quartette.- Alice, Bertram, } \\
\text { Robert, Raimbault and } \\
\text { Gobetto. Air-'Bibi-Bamban' }\end{array}$ & $\begin{array}{l}\text { Composer listed on the programme as Arban. Arban's 'Bibi- } \\
\text { Bamban' appears in the catalogues of the Bibliothèque } \\
\text { nationale de France as a quadrille on comic songs by } \\
\text { Lhuillier, Offenbach, \& Marc-Chautagne. }{ }^{170}\end{array}$ \\
\hline $\begin{array}{l}\text { Air changes to 'Ah qu'elles } \\
\text { sont bonnes les pommes' }\end{array}$ & $\begin{array}{l}\text { From Offenbach's La belle Hélène. This probably refers to } \\
\text { 'L'homme à la pomme' }\end{array}$ \\
\hline $\begin{array}{l}\text { Quartette.-Robert, Isabella, } \\
\text { Alice, and Raimbault. Air- } \\
\text { 'Le chateau [sic] de } \\
\text { Kaoutchou' }\end{array}$ & $\begin{array}{l}\text { 'Le Château de Ka-ou-tchou' by Marc Chautagne, composer } \\
\text { known for comic songs and operetta. }\end{array}$ \\
\hline $\begin{array}{l}\text { Quintette.-Robert, Bertram, } \\
\text { Alice. Air-'Digue, digue, }\end{array}$ & $\begin{array}{l}\text { Tu connais ce secret terrible' from Offenbach's L'île de } \\
\text { Tulipatan. }\end{array}$ \\
\hline
\end{tabular}

169 The manuscript is available at the British Library: Add MS 53073 D.

${ }^{170}$ See http://data.bnf.fr/14821066/marc chautagne/ [accessed 23/02/2016]. 


\begin{tabular}{|c|c|}
\hline $\begin{array}{l}\text { digue' (L'Ile [sic] de } \\
\text { Tulipatan). }\end{array}$ & \\
\hline $\begin{array}{l}\text { (Air changes to finale to L'Ile } \\
\text { [sic] de Tulipatan) }\end{array}$ & \\
\hline $\begin{array}{l}\text { Chorus of Wax Figures. Air.- } \\
\text { 'A fosco cielo' }\end{array}$ & Bellini, La Sonnambula \\
\hline $\begin{array}{l}\text { Trio.--Robert, Bertram, and } \\
\text { Gobetto. Air-From Le Dieu } \\
\text { et la Bayadère }\end{array}$ & (Auber) The particular number is not specified. \\
\hline $\begin{array}{l}\text { (Air-'Allons gais } \\
\text { chausseurs') }\end{array}$ & Hervé, L'œil Crevé \\
\hline $\begin{array}{l}\text { Duet and Chorus-Isabella, } \\
\text { and Prince of Grenada. Air- } \\
\text { 'Le trouvaille du P'tiot Ivon' }\end{array}$ & $\begin{array}{l}\text { Victor Robillard, French arranger and composer of comic } \\
\text { songs. }\end{array}$ \\
\hline $\begin{array}{l}\text { (Air changes to 'Irish } \\
\text { Washerwoman') }\end{array}$ & Traditional jig dating from the late $16^{\text {th }} /$ early $17^{\text {th }}$ century. \\
\hline $\begin{array}{l}\text { Duet-Bertram and Gobetto. } \\
\text { (Air from Les Deux Bavards) }\end{array}$ & $\begin{array}{l}\text { Les bavards is an operetta by Offenbach. The particular } \\
\text { number is not specified. The lyrics suggest that they might } \\
\text { have been set to the tune of 'Quel bavard insupportable', } \\
\text { but it is not certain. }\end{array}$ \\
\hline $\begin{array}{l}\text { Air changes to 'Proclamation } \\
\text { de Popolani' (Barbe Bleue). }\end{array}$ & $\begin{array}{l}\text { From Offenbach's Barbe-bleue. This probably refers to } \\
\text { 'J'apporte les volontés', which is the only substantial solo for } \\
\text { the character Popolani. The new lyrics also fit the melody. }\end{array}$ \\
\hline $\begin{array}{l}\text { Quartette.-Robert, Bertram, } \\
\text { Isabella, and Raimbault. Air- } \\
\text { 'Mon Oscar' }\end{array}$ & $\begin{array}{l}\text { Jules Javolet, composer of comic opera and writer of violin } \\
\text { methods. 'Mon Oscar' was likely a number from one of his } \\
\text { operettas, but its provenance is not specified in the libretto } \\
\text { or playbill. }\end{array}$ \\
\hline $\begin{array}{l}\text { Air changes to 'Loup y es tu?' } \\
\text { (Bibi Bamban) }\end{array}$ & $\begin{array}{l}\text { This is probably also from Arban's quadrille on songs from } \\
\text { operettas. }\end{array}$ \\
\hline $\begin{array}{l}\text { Song.- Robert and Bertram. } \\
\text { Air -'My Father's Farm' }\end{array}$ & $\begin{array}{l}\text { Full title: 'When I was a lad on me father's farm'. Early } \\
\text { version of 'Old MacDonald had a farm.' }{ }^{171}\end{array}$ \\
\hline $\begin{array}{l}\text { Finale. Bertram, Robert, Alice, } \\
\text { Isabella, Gobetto, Raimbault } \\
\text { and Chorus. Air-'Logeons le } \\
\text { donc, et dès ce soir' }\end{array}$ & Offenbach, La Grande Duchesse de Gérolstein \\
\hline
\end{tabular}

The music was fresh: La belle Hélène had premiered in 1864 and had also recently appeared at the St James's Theatre in 1867, L'œil Crevé premiered in 1867 and La

${ }^{171}$ At the premiere this song was not included. It was added in a revised and abridged version, in which all numbers from 'Allons gais chausseurs' to 'Loup y es tu?' were cut. The abridged version is available at the British Library: W. S. Gilbert, Robert the Devil; or, The Nun, The Dun, and the Son of a Gun (London, n.d.). The Bodleian Library holds a copy of the original version. 
Grande Duchesse and L'île de Tulipatan were even more recent, having only premiered in Paris a couple of months before Robert the Devil. ${ }^{172}$ Musical choices, therefore, were based on the desire to advertise new, fashionable products which the bourgeoisie might like to consume. Tellingly, the playbill advertising Robert the Devil (Plate 4) provided details of the music used in the performance, including the composer, the original works the pieces were from, and the publishers who had granted permission to perform the songs. This practice was unique to the Gaiety and appears to have been a marketing tool to make it easy for audiences to purchase the music. ${ }^{173}$ Publishers likely saw the Gaiety's burlesque productions as an excellent means of advertising new music to an eager bourgeois market. ${ }^{174}$

Hollingshead catered for the fashionable, commercial tastes of his audience in several other ways. One strategy was to sell programmes printed on scented fans (see Plate 3), satisfying the upper-middle-class desire for luxury commodities as a symbol of social standing. Later Gaiety programmes were printed on silk. ${ }^{175}$ The programmes for the opening night of Robert the Devil also included adverts for luxury items, including beauty products, horticultural decorations 'for homes of taste', perfume, and "crests and initials embroidered or designed", suggesting that the audience included some of the nouveau riche aspiring to acquire aristocratic lineage. ${ }^{176}$

\section{Plate 3: Programme for Robert the Devil, Gaiety Theatre $\mathbf{1 8 6 8}^{177}$}

Rappaport has argued that West End productions were comparable with shop windows, displaying richly decorated sets, costumes, and props, and acting as an extension of the fashionable shopping district of which they were part. ${ }^{178}$ This certainly seems to be true of the Gaiety's Robert the Devil production, in which the musical selections were displayed for consumer-spectators just as desirable objects and settings were. The musical choices, the way they were presented, the elegant programmes, the advertising, and the spectacle of the ornate theatre itself all aligned the Gaiety with the commercial pleasures associated with the West End, making the Gaiety's burlesque offering a natural extension of the day's shopping. ${ }^{179}$

\section{Plate 4: Playbill, Robert the Devil, 21 December 1868}

\footnotetext{
${ }^{172}$ For details of these premieres see Richard Traubner, Operetta: A Theatrical History (London, 1984), 22-49.

173 Playbills advertising burlesques at other theatres contained an overview of the plot and scene changes, but contained no information about the music, other than crediting the arranger. At most burlesques patrons could buy programme booklets, which contained dialogue. Programme booklets included (often misspelled) titles of the musical numbers and so could function in a similar way, but they did not usually reference the composer, the original opera, or publisher.

${ }^{174}$ Typical means used by publishers to advertise music included press reviews and soirées in which new ballads were showcased. See Scott, The Singing Bourgeoisie, 56-7.

${ }^{175}$ An example can be found at the $V \mathcal{E} A$. An image is available here:

http://collections.vam.ac.uk/item/O132946/silk-programme-r-ward-sons/ [accessed 23/o2/2016].

${ }^{176}$ Adverts from 'Robert the Devil' Gaiety programme booklet, 21 December 1868, 'Theatre Box: Gaiety 1868', VEA.

177 (C) Victoria and Albert Museum, London. Reproduced with permission.

${ }_{178}$ Rappaport, Shopping for Pleasure, 183-4.

179 Rappaport has argued that audiences associated theatregoing with shopping, rather than treating it as an isolated experience. See Rappaport, Shopping for Pleasure, 183.
} 
The non-operetta choices in Robert the Devil were drawn from opera and traditional airs and folksongs (the traditional items were not advertised on the programme). Music hall was conspicuous by its absence. This was not appropriate for Gaiety audiences. A music hall song did appear in a burlesque at the Gaiety in 1885, but it was sneered at in the press. A review of Frank Burnand's Mazeppa describes the vulgar response of those in the pit and gallery to the incorporation of the popular music hall song 'What cheer, Ria?':

The object of the song was that delight of the lower orders - noise. The more the "profanum vulgus" screams the merrier they become...such a din is heard as never before echoed within the walls of this solemn place of mirth [The Gaiety]. ${ }^{180}$

The reviewer also expressed surprise that this 'democratic ditty' should be heard in the 'aristocratic' Gaiety. The reviewer finished the piece by speculating sarcastically that, as 'What cheer, Ria?' had travelled as far as the Gaiety, it may continue climbing the social ladder and be introduced in aristocratic balls. The review suggests that members of the lower orders were in the audience, but it was not usually the Gaiety's policy to cater to their tastes. Music hall did not corroborate the Gaiety's identity, or indeed that of its audience. Overall, the musical choices at the Gaiety carefully constructed a fashionable, upper-middle-class audience. Any popular music programmed was not intended to disrupt the audience's sense of a cultural or social hierarchy. The fact that it did in the case of Mazeppa was precisely because music hall was so unusual at the Gaiety, strongly suggesting that cultural subversion was not typical of burlesque at this time and in this theatre. In the particular case of the Gaiety, the homogeneity of the music suggests that Hollingshead did not intend to expand his clientele, but rather he was trying to attract a particular type of audience member: one who was wealthy, and enjoyed luxury, fashion, and frivolity.

This article has put forward an unfamiliar image of burlesque. It has argued that midVictorian burlesque was a different beast from its counterpart earlier in the century; gone were the days of cutting satire, cultural subversion, and challenges to social hierarchies. In the second half of the century burlesque became respectable, safe, and thoroughly bourgeois. Nonetheless, researchers have been slow to distinguish between early and late-nineteenth-century burlesques; they tend to project the tendencies of late Georgian and early Victorian burlesque onto burlesques from the mid-Victorian period, assuming that they continued to question cultural and social norms. The result is that burlesque has been divorced from the wider context of the commercial development of the West End and of popular music more generally, which was driven by the appetites of the bourgeoisie. By placing mid-Victorian burlesque in its broader theatrical and musical context, we gain a greater understanding of the impulses driving many of the musical choices and of the audiences at whom this music was aimed. Indeed, if we examine the musical juxtapositions of 'high' and 'low' music through a mid-Victorian rather than a modern-day prism, we begin to understand just

\footnotetext{
${ }^{180}$ Unlabelled newspaper cutting dated 21 May 1885, 'Theatre Box: Gaiety 1885', VEA [Date added post hoc].
} 
how commercial, and just how far from incongruous or dissonant the respectable musical pairings were.

As the West End became a respectable site of mass consumerism and a fashionable centre of pleasure and entertainment through the 186os, the minor theatres found new ways to appeal to their most important consumers: the bourgeoisie. This does not mean that burlesques were attended solely by the bourgeoisie, but this article has argued that writers, producers, and musical arrangers imagined their audiences as middle class and deliberately courted this group. Nonetheless, the heterogeneity, ambiguity, and fluidity of this group, coupled with the separate histories and aims of the theatres themselves, and the time the performances were given, led the theatres to adopt different strategies. This article has deliberately examined burlesques performed at three theatres within a similar geographical area, with seemingly comparable clienteles, within a narrow chronological period to illustrate the considerable differences that can be found even within these relatively narrow parameters. Burlesque itself was a fluid, hybrid genre, which made it a perfect vehicle to attract this audience. Each theatre capitalised on a different aspect of burlesque: at the St James's Lucrezia Borgia! was similar to early continental opera adaptation, at the Prince of Wales's variety was key and here burlesque was similar to ballad opera, whilst the Gaiety's burlesque was almost an operetta, catering to the tastes of its particular share of the bourgeois consumer group, capitalising on the developed commercial strategies of the broader West End area.

Overall, mid-Victorian burlesques can shed light on how a group of people who are often the subject of historical enquiry, but are notoriously difficult to define, were constructed by mid-Victorian theatre managers, and perhaps how they imagined themselves. The fact that burlesques were involved in consolidating identity and social boundaries in a time of flux shows that they did play an important social role: just not the one with which they have been associated. The image of the bourgeoisie that emerges from mid-Victorian burlesque is of a social group defined by broad commonalities, including respectability, commodity culture, and domestic musicmaking, but with a conflicted relationship to opera, to which burlesque producers were sensitive. The ability of producers to understand and cater for consumer differences enabled mid-Victorian burlesque to become an extension of a fashionable shopping district and an important part of the West End 'theatrical theme park' ${ }^{181}$

\section{Appendix}

Table 1: Ticket Prices at the St James's Theatre February $1859^{182}$

\begin{tabular}{|l|l|}
\hline Private Boxes & $\begin{array}{l} \pm 33 \mathrm{~s} \\
£ 22 \mathrm{~s} .\end{array}$ \\
\hline Stalls & $1056 \mathrm{~d}$ \\
\hline Box seats & $4 \mathrm{~s}$ \\
\hline Pit & $2 \mathrm{~s} 6 \mathrm{~d}$ \\
\hline
\end{tabular}

${ }^{181}$ Davis and Emeljanow's term - see Reflecting the Audience, 173.

${ }^{182}$ Based on prices on playbills from February 1859, 'Theatre Box: St James's Theatre 1859', VEA. 


\begin{tabular}{|l|l|}
\hline Amphitheatre Stalls & 1s $6 \mathrm{~d}$ \\
\hline Gallery & is \\
\hline
\end{tabular}

Table 2: Prices at the Prince of Wales's Theatre $1865^{183}$

\begin{tabular}{|l|l|}
\hline Private Boxes & $\begin{array}{l}£ 2 \text { 2s } \\
£ 1 \text { 11s 6d and } 1 \text { Guinea }\end{array}$ \\
\hline Stalls & $6 \mathrm{~s}$ \\
\hline Dress Circle & $3 \mathrm{~s}$ \\
\hline Pit & $1 \mathrm{~s} 6 \mathrm{~d}$ \\
\hline Amphitheatre stalls & $1 \mathrm{1s} 6 \mathrm{~d}$ \\
\hline Gallery & $6 \mathrm{~d}$ \\
\hline
\end{tabular}

Table 3: Prices at the Gaiety Theatre $\mathbf{1 8 6 8}^{184}$

\begin{tabular}{|l|l|}
\hline Private Boxes & $\begin{array}{l}£ 2 \text { 2S } \\
£ 1 \text { 11s 6d }\end{array}$ \\
\hline Orchestra Stalls & $7 \mathrm{~s}$ \\
\hline Balcony Stalls & $5 \mathrm{~S}$ \\
\hline Upper boxes & $4 \mathrm{~S}$ \\
\hline Pit & $2 \mathrm{~S}$ \\
\hline Gallery & is \\
\hline
\end{tabular}

Table 4: Prices at the St James's Theatre October $1859^{185}$

\begin{tabular}{|l|l|}
\hline Private Boxes & $\begin{array}{l} \pm 2 \text { 2s } \\
\pm 1 \text { 11s 6d } \\
1056 \mathrm{~d}\end{array}$ \\
\hline Stalls & $5 \mathrm{~s}$ \\
\hline Dress circle & $3 \mathrm{~s}$ \\
\hline Upper circle & $2 \mathrm{~s}$ \\
\hline Pit & $1 \mathrm{~s}$ \\
\hline Gallery & $6 \mathrm{~d}$ \\
\hline
\end{tabular}

${ }^{183}$ Based on playbills at the Prince of Wales's theatre 1865, 'Theatre Box: Prince of Wales's Theatre 1865', $V \mathcal{E} A$.

184 Based on playbills for Robert the Devil, 21 December 1868, 'Theatre Box: Gaiety 1868', VEA.

${ }^{185}$ Based on prices on playbills from October 1859, 'Theatre Box: St James's Theatre 1859', VEA. 
